\title{
CEsifo \\ WORKING

\section{Shedding Light on the Shadow Economy: A Global Database and the Interaction with the Official One}

Leandro Medina, Friedrich Schneider 


\section{Impressum:}

CESifo Working Papers

ISSN 2364-1428 (electronic version)

Publisher and distributor: Munich Society for the Promotion of Economic Research - CESifo

$\mathrm{GmbH}$

The international platform of Ludwigs-Maximilians University's Center for Economic Studies and the ifo Institute

Poschingerstr. 5, 81679 Munich, Germany

Telephone +49 (0)89 2180-2740, Telefax +49 (0)89 2180-17845, email office@cesifo.de

Editor: Clemens Fuest

www.cesifo-group.org/wp

An electronic version of the paper may be downloaded

- from the SSRN website: www.SSRN.com

- from the RePEc website: www.RePEc.org

- from the CESifo website: www.CESifo-group.org/wp 


\title{
Shedding Light on the Shadow Economy: A Global Database and the Interaction with the Official One
}

\begin{abstract}
Using the multiple indicator-multiple cause (MIMIC) approach, this paper generates a novel global database by estimating the size of the shadow economy for 157 countries over 1991 to 2017. The results suggest that the OECD countries are by far the lowest with values below 20\% of off official GDP and the shadow economy is larger in Latin America and Sub-Saharan Africa, averaging almost 38 and 39 percent of GDP, respectively. The average over all countries and over 1991 to 2017 is $30.9 \%$. What is really remarkable, that the average decline of the shadow economy from 1991 to 2017 is 6.8 percentage points. The shadow economy is particularly large in countries such as Bolivia (Georgia) with 62.9(61.7) percent of GDP, and low in countries such as Switzerland(United States) with 6.4 (7.6) percent of GDP, on average. Robustness tests include the use of satellite data on night lights intensity as a proxy for the size of countries' economies and the comparison of the results with 23 countries national statistical offices' measures of informality (discrepancy method used) demonstrate stable and similar results. Finally the interaction of the shadow economy with the official one is investigated. Theoretically the effect of the shadow economy on the official is an open question; first results of this interaction in Pakistan over 1976 to 2015 show a negative (positive) effect in the short (long) run.
\end{abstract}

JEL-Codes: C390, C510, C820, H110, H260, U170.

Keywords: shadow economy, informal economy, survey, multiple indicators multiple Causes (MIMIC), comparison of different estimation methods, the light intensity approach, shadow economy results for 157 countries, interaction of the shadow economy with the official one.

Leandro Medina

Strategy, Policy and Review Department

International Monetary Fund, IMF

Washington D.C. / USA

Imedina@imf.org
Friedrich Schneider

Research Institute of Banking and Finance Johannes Kepler University of Linz

Austria-4040 Linz

friedrich.schneider@jku.at

December 2, 2019, $2^{\text {nd }}$ version

A first version of this paper was presented at the 7th IMF Statistical Forum "Measury the Informal Economy”, November 14 - 15, 2019, IMF-Headquarters, Washington, D.C. 


\section{TABLE OF CONTENT}

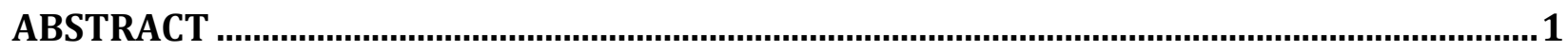

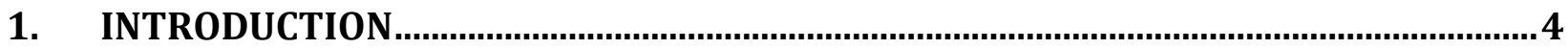

2. METHODS TO MEASURE THE SHADOW ECONOMY ......................................................

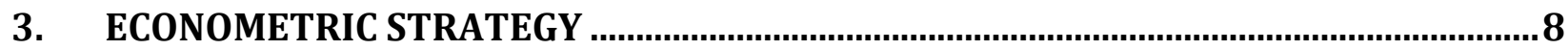

4. ECONOMETRIC MIMIC RESULTS AND SIZE OF THE SHADOW ECONOMY ............... 10

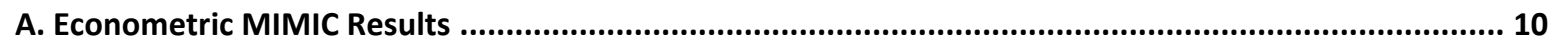

B. Size of the Shadow Economy of 157 countries over 1991 to 2017 Using the $\quad$ MIMIC approach........... 11

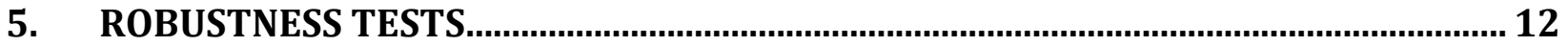

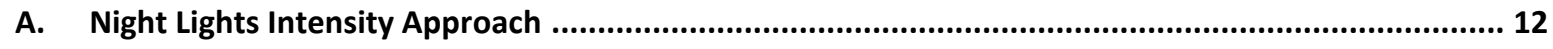

B.

1) MIMIC Results Versus National Accounts (Discrepancy Method) Results: OECD Countries.................... 12

2) MIMIC Results versus National Accounts (Discrepancy - Method) Results: Developing countries......... 13

6. SOME REMARKS ABOUT THE INTERACTIONS BETWEEN THE OFFICIAL AND

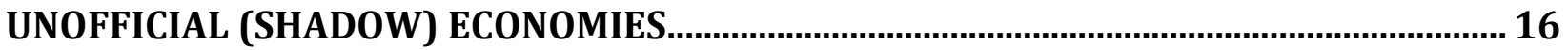

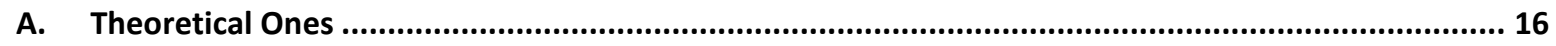

B. Interaction between Official Sector and Shadow Economy in Pakistan over 1976 to 2015 Empirical

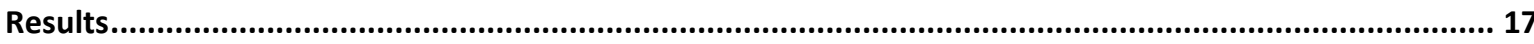

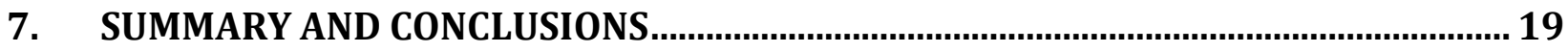

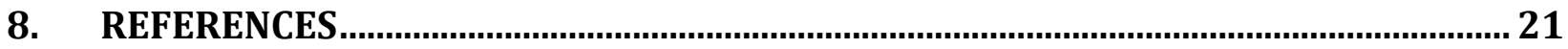

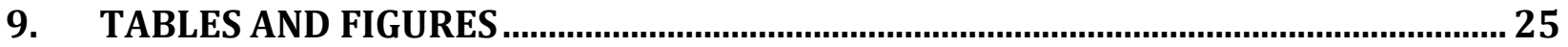

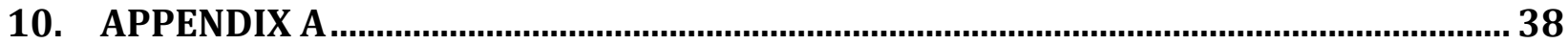




\section{INTRODUCTION}

The definition, size and key characteristics of the shadow economy have been the reason of many debates in both policy and academic circles. Recent global developments, such as migration waves, climate change, and trade tensions have triggered a renewed interest in the vicissitudes surrounding the shadow economy.

Its definition and measurement has been a subject of controversy. The shadow economy is known by different names, such as the hidden economy, gray economy, black economy or lack economy, cash economy or informal economy. All these synonyms refer to some type of shadow economy activities and have been used frequently, and quite inconsistently. Feige $(1979,1996)$ argues that the informal economy comprises economic activities that circumvent costs and are excluded from the benefits and rights incorporated in laws and administrative rules covering property relationships, commercial licensing, labor contracts, tors, financial credit and social systems.

This paper defines the shadow or informal economy as all economic activities which are hidden from official authorities for monetary, regulatory, and institutional reasons. Monetary reasons include avoiding paying taxes and all social security contributions, regulatory reasons include avoiding governmental bureaucracy or the burden of regulatory framework, while institutional reasons include corruption law, the quality of political institutions and weak rule of law. The shadow economy, in this paper, reflects mostly legal economic and productive activities that, if recorded, would contribute to national GDP, therefore the definition of the shadow economy in our study tries to avoid illegal or criminal activities, do-it-yourself, or other household activities. ${ }^{1}$

In addition to the difficulty associated to the shadow economy definition, its size is also difficult to measure, as agents engaged in these activities try to remain undetected. The request for information about the extent of the shadow economy and its developments over time is motivated by its political and economic relevance. Moreover, total economic activity, including official and unofficial production of goods and services is essential in the design of economic policies that respond to fluctuations and economic development over time and across space. Furthermore, the size of the shadow economy is a core input to estimate the extent of tax evasion and thus for decisions on its adequate control.

Different methods have been proposed to estimate the size of the informal economy. Direct approaches, mostly based on surveys and samples, rely on voluntary replies, or tax auditing and other compliance methods to measure the informal economy; the results are sensitive to how the questionnaire is formulated and therefore unlikely to capture all informal activities.

Indirect approaches, also called indicator approaches, use indirect information to estimate the size of the informal economy. For example, the discrepancy between the official and actual labor force approach states that a decline in labor force participation in the official economy can be seen as an indication of an increase in the size of the informal economy, if total labor force participation is

1 Of course, we are aware that there are overlapping areas, like prostitution, illegal construction firms or corruption, compare e.g. Dreher and Schneider (2009), Dreher and Katsogrannis (2009), Williams and Schneider (2016), Schneider (2017), and Medina and Schneider (2018) compare also section 2, where this problem is tackled. 
assumed to be constant. Most direct and indirect methods consider just one indicator of all effects of the informal economy.

The literature has, more recently, relied on the multiple indicator-multiple cause (MIMIC) models, which explicitly consider causes and indicators of the shadow economy and treat the shadow economy as an unobserved component. ${ }^{2}$

Although widely used, MIMIC methods have been criticized, in particular for: (i) the use of GDP per capita and growth of GDP per capita as cause and indicator of the size of the shadow economy, (ii) the fact that these models need an independent study to calibrate the model, and (iii) some evidence that the coefficients may be sensitive to alternative specifications, and chosen country and time span. ${ }^{3}$

Against this background, this paper contributes to the literature and addresses concerns by: (i) developing, to our knowledge, one of the most comprehensive databases of the size of the shadow economy, which covers 157 countries over 1991-2017, which is done by using a modified version of the Multiple Indicator-Multiple Cause (MIMIC) model on a number of causes and indicator variables; (ii) addressing criticism related to the use of GDP; by using the night light intensity (night lights as measured by satellites) as alternative measure of the size of the economy; and (iii) comparing the results with the official estimations from countries' statistic offices. Additionally, and as the interaction between the shadow economy and the official one, becomes more and more important, this paper includes a brief section about this topic.

The paper is organized as follows: In section 2 a brief discussion of the methods to measure the shadow economy is undertaken. Section 3 discusses the econometric strategy, the MIMIC approach, and in section 4 the econometric MIMIC estimation findings and results at the shadow economy for the 157 countries over 1991 to are shown. Section 5 presents some robustness' tests. Section 6 gives some brief theoretical remarks about the interactions between the official and unofficial (shadow) economies and shows some first empirical results for Pakistan. In Section 7 a summary and policy conclusions are given.

\section{Methods to Measure The Shadow Economy}

Individuals are rational calculators who weigh up costs and benefits when considering breaking the law. Their decision to partially or completely participate in the shadow economy is a choice overshadowed by uncertainty, as it involves a trade-off between gains, if their activities are not discovered, and losses, if they are discovered and penalized. Shadow economic activities SE thus negatively depend on the probability of detection $\mathrm{p}$ and potential fines $\mathrm{f}$, and positively on the opportunity costs of remaining formal, denoted as B. The opportunity costs are positively determined by the burden of taxation $\mathrm{T}$ and high labor costs $\mathrm{W}$ - individual income generated in the shadow economy is usually categorized as labor income rather than capital income - due to labor market regulations. Hence, the higher the tax burden and labor costs, the more incentives

2 Examples of this growing literature include the seminal papers by Schneider and Enste (2000, 2002), Gerxhani (2003), Feld and Schneider (2005, 2010,2011), Hassan and Schneider (2016), Schneider (2017) and Medina and Schneider (2018)

3 For recent debates and controversies compare Kirchgaessner (2016), Feld and Schneider(2016), Breusch (2016), Feige (2016a, b), Schneider (2016) and Hashimzade and Heady (2016). 
individuals have to avoid these costs by working in the shadow economy. The probability of detection $\mathrm{p}$ itself depends on enforcement actions A taken by the tax authority and on facilitating activities $\mathrm{F}$ accomplished by individuals to reduce the detection of shadow economic activities. This discussion suggests the following structural equation:

$$
S E=S E[\bar{p}(\stackrel{+}{A}, \stackrel{-}{F}) ; \bar{f} ; \stackrel{+}{B}(\stackrel{+}{T}, \stackrel{+}{W})]
$$

Hence, shadow economic activities may be defined as those economic activities and income earned that circumvent government regulation, taxation or observation. More narrowly, the shadow economy includes monetary and non-monetary transactions of a legal nature; hence all productive economic activities that would generally be taxable were they reported to the state (tax) authorities. Such activities are deliberately concealed from public authorities to avoid payment of income, value added or other taxes and social security contributions, or to avoid compliance with certain legal labor market standards such as minimum wages, maximum working hours, or safety standards and administrative procedures. The shadow economy thus focuses on productive economic activities that would normally be included in national accounts, but which remain underground due to tax or regulatory burdens. ${ }^{4}$ Although such legal activities would contribute to a country's value added, they are not captured in national accounts because they are produced in illicit ways. Informal household economic activities such as do-it-yourself activities and neighborly help are typically excluded from the analysis of the shadow economy. ${ }^{5}$

Based on these considerations. A variety of methods have been used by the literature over the years to measure the size of the shadow economy. These methods can be aggregated into direct or indirect (including the model-based ones). ${ }^{6}$

The most common direct approaches to measuring the size of the informal economy rely on surveys and samples based on voluntary replies, or tax auditing and other compliance methods. While providing great detail about the structure of the informal economy, the results are sensitive to the way the questionnaire is formulated and respondents' willingness to cooperate. Consequently, surveys are unlikely to capture all informal activities. ${ }^{7}$

Indirect approaches, alternatively called "indicator" approaches, are mostly macroeconomic in nature. These are in part based on: (i) the discrepancy between national expenditure and income statistics; (ii) the discrepancy between the official and actual labor force; (iii) the "electricity

4 Although classical crime activities such as drug dealing are independent of increasing taxes and the causal variables included in the empirical models are only imperfectly linked (or causal) to classical crime activities, the footprints used to indicate shadow economic activities such as currency in circulation also apply for classic crime. Hence, macroeconomic shadow economy estimates do not typically distinguish legal from illegal underground activities; instead they represent the whole informal economy spectrum.

5 From a social perspective, maybe even from an economic one, soft forms of illicit employment such as moonlighting (e.g. construction work in private homes) and its contribution to aggregate value added may be assessed positively. For a discussion of these issues, see Thomas (1992) and Buehn, Karmann and Schneider (2009).

6 This section follows Schneider and Enste (2002), and Feld and Schneider (2010), and Schneider (2017).

7 See Isanchen and Strom (1985), Witte (1987), Mogensen et al. (1995), and Feige (1996). 
consumption" approach of Kauffman and Kaliberda (1996); (iv) the "monetary transaction" approach of Feige (1979); (v) the "currency demand" approach of Cagan (1958) and others; and (vi) the "Multiple Indicators, Multiple Causes" (MIMIC). Specifically:

(i) Discrepancy between national expenditure and income statistics: If those working in the informal economy were able to hide their incomes for tax purposes but not their expenditure, then the difference between national income and national expenditure estimates could be used to approximate the size of the informal economy. This approach assumes that all the components of the expenditure side are measured without error and constructed so that they are statistically independent from income factors. ${ }^{8}$

(ii) Discrepancy between official and actual labor force: If the total labor force participation is assumed to be constant, a decline in official labor force participation can be interpreted as an increase in the importance of the informal economy. Since fluctuation in the participation rate might have many other explanations, such as the position in the business cycle, difficulty in finding a job and education and retirement decisions, but these estimates represent weak indicators of the size of the informal economy. ${ }^{9}$

(iii) Electricity approach: Kaufmann and Kaliberda (1996) endorse the idea that electricity consumption is the single best physical indicator of overall (official and unofficial) economic activity. Using findings that indicate the electricity-overall GDP elasticity is close to one, these authors suggest using the difference between growth of electricity consumption and growth of official GDP as a proxy for the growth of the informal economy. This method is simple and appealing, but has many drawbacks, including: (i) not all informal economy activities require a considerable amount of electricity (e.g. personal services) or the use of other energy sources (like coal, gas, etc.), hence only part of the informal economy growth is captured; and (ii) the electricity-overall GDP elasticity might significantly vary across countries and over time. ${ }^{10}$

(iv) Transaction approach: Using Fischer's quantity equation, Money*Velocity = Prices*Transactions, and assuming that there is a constant relationship between the money flows related to transactions and the total (official and unofficial) value added, i.e. Prices $*$ Transactions $=k$ (official GDP + informal economy), it is reasonable to derive the following equation Money $*$ Velocity $=k$ (official GDP + informal economy). The stock of money and official GDP estimates are known, and money velocity can be estimated. Thus, if the size of the informal economy as a ratio of the official economy is known for a benchmark year, then the informal economy can be calculated for the rest of the sample. Although theoretically attractive, this method has several weaknesses, for instance: (i) the assumption of $k$ constant over time seems quite

See for example MacAfee (1980), and Yoo and Hyun (1998).

9 See for example Contini (1981), Del Boca (1981), and O’Neil (1983).

10 See for example Del Boca and Forte (1982), Portes (1996) and Johnson et al. (1997). 
arbitrary; and (ii) other factors like the development of checks and credit cards could also affect the desired amount of cash holdings and thus velocity. ${ }^{11}$

(v) Currency demand approach: Assuming that informal transactions take the form of cash payments, in order not to leave an observable trace for the authorities, an increase in the size of the informal economy will, consequently, increase the demand for currency. To isolate this "excess" demand for currency, Tanzi (1980) suggests using a time series approach in which currency demand is a function of conventional factors, such as the evolution of income, payment practices and interest rates, and factors causing people to work in the informal economy, like the direct and indirect tax burden, government regulation and the complexity of the tax system. However, there are several problems associated with this method and its assumptions: (i) this procedure may underestimate the size of the informal economy, because not all transactions take place using cash as means of exchange; (ii) increases in currency demand deposits may occur because of a slowdown in demand deposits rather than an increase in currency used in informal activities; (iii) it seems arbitrary to assume equal velocity of money in both types of economies; and (iv) the assumption of no informal economy in a base year is arguable. ${ }^{12}$

(vi) Multiple Indicators, Multiple Causes (MIMIC) approach: This method explicitly considers several causes, as well as the multiple effects, of the informal economy. The methodology makes use of the associations between the observable causes and the effects of an unobserved variable, in this case the informal economy, to estimate the variable itself (Loayza, 1997). ${ }^{13}$

\section{ECONOMETRIC STRATEGY}

Most of the methods described above consider only one (either direct or indirect) indicator of the informal economy, such as electricity consumption or money demand. However, there may exist more than one manifestation or symptom of the informal economy showing up simultaneously.

This paper uses the MIMIC approach, as it explicitly considers various causes, as well as several effects of the informal economy. The model exploits the associations between observable causes and effects of the unobserved informal economy to estimate the size of the informal economy itself. ${ }^{14}$ The model can be described as:

$$
\begin{aligned}
& y=\lambda I E+\varepsilon \\
& I E=\gamma^{\prime} x+v
\end{aligned}
$$

11 See for example Feige (1979), Boeschoten and Fase (1984) and Langfeldt (1984).

12 See for example Cagan (1958), Gutmann (1977), Tanzi (1999, 1980, 1983), Kirchgassner (1983), Schneider (1997) and Johnson et al. (1998a, 1998b).

13 See Vuletin (2009), Dell'Anno and Schneider (2009), Dell'Anno (2007), Schneider (2010); Alm and Embaye (2013), Abdih and Medina (2016), Williams and Schneider(2016) and Medina et.al. (2017).

14 See Loayza (1996). 
where IE is the unobservable latent variable, $y^{\prime}=\left(y_{1}, \ldots, y_{p}\right)$ is a vector of indicators for IE, $x^{\prime}=\left(x_{1}, \ldots, x_{q}\right)$ is a vector of causes of IE, $\lambda$ and $\gamma$ are the (px1) and (qx1) vectors of the parameters, and $\varepsilon$ and $v$ are the (px1) and scalar errors. Equation (1) relates the informal economy to its indicators, while equation (2) associates the informal economy with a set of observable causes. Assuming that the errors are normally distributed and mutually uncorrelated with $\operatorname{var}(v)=\sigma_{v}^{2}$ and $\operatorname{cov}(\varepsilon)=\Theta_{\varepsilon}$, the model can be solved for the reduced form as a function of observable variables by combining equations (1) and (2):

$$
y=\pi x+\mu
$$

where $\pi=\lambda \gamma^{\prime}, \mu=\lambda v+\varepsilon_{\text {and }} \operatorname{cov}(\mu)=\lambda \lambda^{\prime} \sigma_{v}^{2}+\Theta_{\varepsilon}$.

As $\mathrm{y}$ and $\mathrm{x}$ are data vectors, equation (3) can be estimated by maximum likelihood using the restrictions implied in both the coefficient matrix $\pi$ and the covariance matrix of the errors $\mu$. Since the reduced form parameters of equation (3) remain unaltered when $\lambda$ is multiplied by a scalar and $\gamma$ and $\sigma_{v}^{2}$ are divided by the same scalar, the estimation of equations (1) and (2) requires a normalization of the parameters in equation (1), and a convenient way to achieve this is to constrain one element of $\lambda$ to some pre-assigned value.

Since the estimation of $\lambda$ and $\gamma$ is obtained by constraining one element of $\lambda$ to an arbitrary value, it is useful to standardize the regression coefficients $\hat{\lambda}_{\text {and }} \hat{\gamma}_{\text {as }} \hat{\lambda}^{s}=\hat{\lambda}\left(\frac{\hat{\sigma}_{I E}}{\hat{\sigma}_{y}}\right)$ and $\hat{\gamma}^{s}=\hat{\gamma}\left(\frac{\hat{\sigma}_{x}}{\hat{\sigma}_{I E}}\right)$

The standardized coefficient measures the expected change (in standard-deviation units) of the dependent variable due to a one standard-deviation change of a given explanatory variable, when all other explanatory variables are held constant. Using the estimates of the $\gamma^{s}$ vector and setting the error term $v$ to its mean value of zero, the predicted values for the informal economy can be estimated using equation (2). Then, by using information for one country from various independent studies regarding the specific size of the informal economy measured in percent of GDP, the ordinal within-sample predictions for the informal economy can be converted into percentages of GDP. 


\section{ECONOMETRIC MIMIC RESULTS AND SIZE OF THE SHADOW ECONOMY}

\section{A. Econometric MIMIC Results}

As explained in the previous section, the MIMIC model assumes specific causes and indicators that can be used to measure the size of the shadow economy. The specialized literature highlights the tax burden or government distortionary policies, labor market rigidities, lack of institutional quality, and product and financial market rigidities as the main causes ${ }^{15}$

The model used in this paper covers a sample of 157 countries over the 1991-2017 time interval. The estimation relies on the following drivers of the shadow economy: (i) a measure of tax burden on the economy, as everything else equal, a larger tax burden is likely to encourage economic agents to remain outside of the formal sector; ${ }^{16}$ (ii) institutional_quality, as weak institutions, such as lack of respect for the law or high levels of corruption, would encourage informal activities; (iii) openness, proxied by trade openness, as economies become more interconnected and trade more with their neighbors and other countries it would be harder to hide these activities from authorities; and (iv) unemployment, as lack of opportunities in the formal sector would force individuals to engage in informal economic activities.

The MIMIC model also uses measurable indicators, such as: (i) currency as a fraction of broad money, as people engaged in the informal economy usually conduct their activities in cash; (ii) labor force participation, as a decline in official labor force participation could signal some giving up searching for work in the formal sector, and (iii) a measure of the size of the economy.

The results for the model (MIMIC) estimation are shown in tables 1, 2 and 3, and each table includes six specifications over the period 1991-2017 for 157 countries (largest sample). ${ }^{17}$ Table 1 contains the estimation results for all countries. All cause variables (trade openness, GDP per capita, unemployment, size of government, fiscal freedom, rule of law, control of corruption, government stability), have the theoretically expected signs, and most of them are highly

15 See, for example, Schneider (2010), Feld and Larsen (2005, 2009), and Schneider and Enste (2000).

16 This paper uses two variables to proxy for these effects: (i) the share of government consumption in GDP, and (ii) a fiscal freedom index produced by the Heritage Foundation. A larger government will be required to raise more taxes which distort economic activity and push economic agents from the formal to informal sector. The fiscal freedom index is equally weighted scores from the top marginal tax rate on personal and corporate income, as well as the share of tax burden in GDP. High marginal rates on personal income will push workers towards the informal sector, just as high marginal rates on corporate income would encourage businesses to move activity to the informal sector.

17 The MIMIC regression includes 151 countries. This estimation generated the coefficients and standard deviations. Following this, during the calibration phase, eight countries were dropped as the time series were not long enough. Specifically, Afghanistan, Macao, Macedonia, Serbia, St. Lucia, St. Vincent and the Grenadines, Sudan, and Tonga. Moreover, for 15 additional countries availability on the drivers' information permitted the estimation of the informal economy, and therefore, were added to the sample. Specifically, Austria, Belgium, Ethiopia, Finland, France, Germany, Greece, Ireland, Italy, Mauritania, Netherlands, Niger, Rwanda, Togo, and United Kingdom. This completes the list of $\mathbf{1 5 7}$ countries with shadow economy estimates (shown in table A1). 
statistically significant. The indicator variables also have the theoretical expected signs and are highly statistically significant. The test statistics are satisfactory.

Table 2 contains the estimation results for 102 developing countries (maximum sample). Here the cause variable rule of law is not statistically significant in specification 1, nor is control of corruption in specification 2 . These variables are significant and show the expected sign in the other specifications. The indicator variable labor force is again highly statistically significant.

Finally, in table 3 results for 27 advanced countries are presented. Here trade openness is not statistically significant in all specifications, but in all other specifications most cause variables have the expected sign and are statistically significant, except government stability and size of government. ${ }^{18}$ The indicator variables are all statistically significant and have the expected signs.

\section{B. Size of the Shadow Economy of 157 countries over 1991 to 2017 Using the MIMIC approach}

In table 4 the most important results (summary statistics) for the 157 countries, listed in alphabetical order are shown. ${ }^{19}$ The mean value of the size of the shadow economy of the 157 countries over 1991 to 2017 is $30.9 \%$ of GDP. The median is 31.2, indicating that both values are quite close to each other, so there is not a strong deviation. The three largest shadow economies are Bolivia with $62.9 \%$, Georgia with $61.7 \%$ and Nigeria with $56.8 \%$ of GDP. The three smallest shadow economies are Switzerland with 6.4\%, United States with 7.6\%, and Austria with 7.9\% of GDP. The average shadow economy of $30.9 \%$ comes close to the Dominican Republic with $31.1 \%$ and Cameroon with $30.8 \%$. of official GDP. Finally, in figures 1 and 2 results of the size of the shadow economy of 15 highest and 15 lowest countries are shown. In Figures 3 and 4 we present some disaggregated results Figure 3 presents the shadow economy by region. What is really remarkable that for all 7 regions we have a negative (falling) trend of the size of the shadow economy over time; meaning that the average size of the shadow economy is considerable lower in the time span 2010-17 compared to 1991-99 The average decline from 1991 to 2017 was 6.8 percentage points. The OECD countries are by far the lowest with values below 20 percent and the Sub Saharan African countries and Latin American countries are the highest with average values above 36 percent (both averages over 1991-2017). Figure 4 presents the results grouped by income. High income countries have the lowest shadow economy and low income countries vice versa. ${ }^{20}$

18 This is plausible, as in advanced countries one would already expect good institutions.

19 For a detailed of the results over all 157 countries and all years see table A1 of the appendix.

20 Many countries, especially in the middle east, have been affected by massive refugee inflows in the last years.. Unfortunately our model does not capture this dimension and therefore, the shadow economies such as Jordan, Lebanon or Turkey could potentially be underestimated. For the same reason Syria's results should be taken with caution. Also China's results should be taken with caution, too, as it is partly a market economy and partly a planned economy. Hence the results might be capturing the informal economy only partly. 


\section{Robustness Tests}

\section{A. Night Lights Intensity Approach}

The standard MIMIC model has been used quite widely in the literature for many years. It has also been the subject of criticism, mainly on the use of GDP (GDP per capita and growth of GDP per capita) as cause and indicator variables. ${ }^{21}$.

To address this issue, instead of using GDP per capita and growth of GDP per capita as cause and indicator variables, we use the night lights approach by Henderson, Storeygard, and Weil (2012) to independently capture economic activity. ${ }^{22}$ In their paper, they use data on light intensity from outer space as a proxy for the "true" economic growth achieved by countries. 23 They also use the estimated elasticity of light intensity with respect to economic growth to produce new estimates of national output for countries deemed to have low statistical capacity. Therefore, by using the night lights approach we address MIMIC criticisms related to the endogeneity of GDP in a novel way, which is totally independent from problematic GDP measures traditionally used (See Medina et al. (2017)).

The main results are showed in table 5, which includes six alternative specifications for the period 1991-2017 for different country samples depending on data availability, using light intensity as an indicator variable. All cause variables (trade openness, unemployment, size of government, fiscal freedom, rule of law, control of corruption, government stability), have the theoretically expected signs, and most of them are highly statistically significant. The indicator variables also have the theoretical expected signs and are mostly highly statistically significant. The test statistics are satisfactory.

\section{B.}

\section{1) MIMIC Results Versus National Accounts (Discrepancy Method) Results: OECD Countries}

The first comparison will be made between the calculation of the shadow economy of the System of National Accounts - discrepancy method and the MIMIC method (macro and adjusted) ${ }^{24}$. The results are shown in Table 6 which contains 16 OECD countries for the years 2011 and 2012 (averages). For most countries, the MIMIC results are considerably larger, especially in the cases of Norway, Mexico, Belgium and Israel. Remarkably, some MIMIC estimates come very close to

21 Other criticisms include the fact that the methodology relies on another independent study to calibrate from standardized values to estimate the size of shadow economy in percent of GDP, and that the estimated coefficients are sensitive to alternative specifications, the country sample and time span chosen. These are extensively discussed in Schneider (2016).

22 Light intensity offers many benefits as a proxy for economic activity. However, there are some weaknesses of light intensity as well which are worth considering. In rural areas, for example, you can have economic activity in the absence of additional light.

23 Data on night lights used in this paper has been obtained from Henderson, Storeygard, and Weil database.

${ }^{24}$ See Appendix B for a detailed explanation of the adjustment process. The adjusted shadow economy values are an attempt to exclude alll criminal activities, do-it-yourself and house hold work and legally bought material, which is included in the non-adjusted macro values. Hence the adjusted values are considerably lower. 
the National Accounts Discrepancy method (both macro and adjusted). For example, in Austria the non-observed economy is 7.5 percent by the National Accounts Discrepancy method and 8.4 percent using the macro MIMIC estimation while the adjusted figure is only 5.5 percent, hence, even lower than the National Accounts Discrepancy method. Also somewhat close are the results for the Czech Republic and for the Slovak Republic, but the MIMIC macro results are considerably higher than those achieved with the National Accounts Discrepancy method. If one makes a comparison between the MIMIC adjusted values and the National Accounts Discrepancy method, the differences shrink considerably. While we have large differences for Norway with 9.7 percentage points, the Slovak Rep. with -7.9 (here the MIMIC adjusted value is lower than that from the National Accounts) and Belgium with 7.1 percentage points, for a number of countries the differences are less than three to four percentage points.

What can we conclude from Table 6? There are still considerable differences between the macro MIMIC approach and the National Accounts Discrepancy method, however, the variance, especially in the National Accounts Discrepancy method, is quite large and the MIMIC results for at least for two or three countries come quite close to this calculation of the shadow economy. Hence, the statement by Gyomai and van de Ven (2014) that the estimates by Schneider would be on average three times as large as the estimates for the non-observed economy in the System of National Accounts and 6.7 times larger than the relevant underground economy estimates should be reconsidered. Also, their statement that macroeconomic MIMIC models produce a large size for the shadow economy and the differences are likely to be in great part caused by unrealistic model assumptions and calibration decisions, at least with the adjusted MIMIC results, should be reconsidered.

\section{2) MIMIC Results versus National Accounts (Discrepancy - Method) Results: Developing countries}

Table 7 shows a comparison between the National Accounts Statistics Discrepancy method and the MIMIC results for eight Sub-Saharan African countries over 2010 to 2014 . Here we have exactly the opposite result compared to Table 6. For most countries, the discrepancy method is considerably higher than the MIMIC results; the same is true when compared to the MIMIC adjusted results. Hence, again, the criticism that the MIMIC estimates are unrealistically large and high may be not true, at least not for these eight Sub-Saharan African countries. In seven out of the eight Sub-Saharan African countries the MIMIC estimation is considerably lower than that obtained using the discrepancy method. For example, in Guinea-Bissau the National Accounts Statistics Discrepancy method estimate is $53.4 \%$ and the MIMIC result is $37.6 \%$, a difference of 15.8 percentage points.

Although some countries provide estimates of the size of the informal economy, using the discrepancy method the data generated by MIMIC model in sections 5A and 5B is still extremely useful. First, not all countries publish own estimations of the shadow economy, second, methodologies and sampling methods may affect the comparability of cross-country estimates. Finally, estimates may be rooted in approaches that fail to take account of recent changes in the domestic economy. In contrast, MIMIC produces panel data for most countries that is comparable and can be used to test statistical relationships. 
Table 6. Comparison of the MIMIC (macro and adjusted) results with National Accounts Method; 16 OECD Countries, year 2011/2012 (av.)

\begin{tabular}{|c|l|c|c|c|c|c|}
\hline \multirow{2}{*}{ No. } & \multirow{2}{*}{ Country } & NOE $(1)$ & \multicolumn{2}{|c|}{ MIMIC } & \multicolumn{2}{c|}{ Difference (MIMIC-NOE) } \\
\cline { 2 - 7 } & & $\begin{array}{c}\text { percent of } \\
\text { GDP }\end{array}$ & Macro (2) & Adj. (3) & $(2)-(1)$ & $(3)-(1)$ \\
\hline 2 & Norway & 1 & 16.48 & 10.7 & 15.48 & 9.7 \\
\hline 5 & Mexico & 15.9 & 29.89 & 19.4 & 13.99 & 3.5 \\
\hline 4 & Belgium & 4.6 & 18.00 & 11.7 & 13.40 & 7.1 \\
\hline 3 & Israel & 6.6 & 19.63 & 12.8 & 13.03 & 6.2 \\
\hline 1 & Slovenia & 10.2 & 22.53 & 14.6 & 12.33 & 4.4 \\
\hline 7 & Sweden & 3 & 14.49 & 9.4 & 11.49 & 6.4 \\
\hline 6 & Hungary & 10.9 & 22.07 & 14.3 & 11.17 & 3.4 \\
\hline 8 & Canada & 2.2 & 10.87 & 7.1 & 8.67 & 4.9 \\
\hline 11 & UK & 2.3 & 9.99 & 6.5 & 7.69 & 4.2 \\
\hline 14 & Italy & 17.5 & 25.0 & 16.3 & 7.54 & -1.2 \\
\hline 12 & Netherlands & 2.3 & 8.10 & 5.3 & 5.80 & 3.0 \\
\hline 13 & France & 6.7 & 11.95 & 7.8 & 5.25 & 1.1 \\
\hline 9 & Poland & 15.4 & 19.19 & 12.5 & 3.79 & -2.9 \\
\hline 10 & Czech Rep. & 8.1 & 11.59 & 7.5 & 3.49 & -0.6 \\
\hline 16 & Austria & 7.5 & 8.4 & 5.5 & 0.94 & -2.0 \\
\hline 15 & Slovak Rep. & 15.6 & 11.9 & 7.7 & $\mathbf{- 3 . 7 2}$ & -7.9 \\
\hline Soury & Gy & & & & \\
\hline
\end{tabular}

Source: Gyomai and van de Ven $(2014$, p. 6$)$ and own calculations. 
Table 7 Comparison between National Accounts Statistics and MIMIC results for eight SubSaharan African countries over 2010-2014

\begin{tabular}{|l|c|c|c|c|c|}
\hline \multirow{2}{*}{ Country } & \multicolumn{2}{|c|}{ Methods (averages over 2010-2014) } & \multicolumn{2}{c|}{ Differences } \\
\cline { 2 - 6 } & $\begin{array}{c}\text { (1) National } \\
\text { Accounts } \\
\text { Statistics })\end{array}$ & (2) MIMIC & $\begin{array}{c}\text { (3) MIMIC } \\
\text { Adjusted }\end{array}$ & $(2)-(1)$ & $(3)-(1)$ \\
& 55 & 32.3 & 21.0 & -22.7 & -34.0 \\
\hline Mali & 53.4 & 37.6 & 24.4 & -15.8 & -29.0 \\
\hline Guinea-Bissau & 43.1 & 31.6 & 20.5 & -11.5 & -22.6 \\
\hline Burkina Faso & 47.5 & 37.9 & 24.6 & -9.6 & -22.9 \\
\hline Senegal & 48.1 & 39.5 & 25.7 & -8.6 & -22.4 \\
\hline Guinea & 40.1 & 34.8 & 22.6 & -5.3 & -17.5 \\
\hline Togo & 55.6 & 52.1 & 33.9 & -3.5 & -21.7 \\
\hline Benin & 34 & 41.9 & 27.2 & 7.9 & -6.8 \\
\hline Côte d'Ivoire & & & & \\
\hline $\begin{array}{l}\text { Correlation: } 0.73 \\
\text { Spearman's Rank Correlation: } 0.857 * * *\end{array}$ & & & & \\
\hline
\end{tabular}

1) Mostly the Discrepancy method is used.

Source: Medina et al. (2017), p. 28 and own calculations. 


\section{Some Remarks about the InTERACTIONS Between the OfFicial AND UNOFFICIAL (SHADOW) ECONOMIES}

\section{A. Theoretical Ones}

Obviously there are many interactions between the official (registered) and unofficial (shadow) economies all over the world. Hence, a strict separation of these two parts of the economy is not possible. Therefore, it is not surprising that there is a continuous interaction between the official and unofficial economies. Schneider (2005, 2010) and Schneider and Enste (2000, 2002) emphasize that the official part of the economy could never work efficiently if it were totally separated (disentangled) from the unofficial part. A study carried out by the OECD highlights these concerns further, that the shadow economy permanently competes with the official economy; on the other hand, Lubell (1991) and Schneider (2005) state that the formal and informal economies also complement each other. Other studies (Besozzi (2001) and Schneider (2005)) show that a certain influence of the shadow economy on the efficient functioning and development of the official economy cannot be denied.

In principle, these interactions stem from three main topics that are influenced by the shadow economy, namely taxation, general locations and biased effects of economic policies. The interactions and their effects originating from these three main sources are shown in Table 7.

Various studies, for example Schneider (2005, 2006) and Williams and Schneider (2016) demonstrate that the interaction between the official and the shadow economy takes place but still their results are discussed controversially, especially whether the positive effects dominate over negative ones or vice versa. As these effects always depend on the concrete size of the shadow economy, the intensity of the interaction between the formal and informal sectors and the specific economic situation of a country, an answer can only be given after a careful empirical analysis is undertaken for concrete countries.

In order to study the effects of the underground economy on the official one, the underground economy or shadow economy has been integrated into macroeconomic models. This ends in an extended macro model of the business cycle, as well as tax and monetary policy linkages with the shadow economy. As a result, it becomes clear that these effects should be taken into account for tax and regulatory policies. The presence of a shadow economy tends to overstate the inflationary effect of a fiscal or monetary stimulus and tends to understate the respective effects of unemployment. When the growth of the shadow economy and the official economy are positively related (which is likely to be the case when entry costs into the shadow economy are low due to the probability of enforcement), an expenditure fiscal policy has a positive stimulus for both the formal and the informal economies. The underground economy is a beneficiary in so far as it responds to the economic environmental demands for urban services and small scale manufacturing. These sectors provide the economy with dynamic and entrepreneurial spirit and can strengthen competition, increase efficiency, and put effective limits on government activities. These sectors contribute to the creation of markets, increase financial resources and transform the legal, social and economic institutions necessary for accumulation. Moreover, a substantial part

(up to $70 \%$ of the earnings gained in the shadow economy) is quickly spent in the official sector 
and thus boosts the demand in the official economy. These expenditures tend to raise consumer expenditures as well as (mostly indirect) tax revenues. Theoretically, the effect of the shadow economy on the official one and vice versa is an open question. It is really an empirical question which will be investigated for the case of Pakistan.

\section{B. Interaction between Official Sector and Shadow Economy in Pakistan over 1976 to 2015 Empirical Results ${ }^{25}$}

One of the main research questions about existence of shadow economy is how it effects the official sector? This question is investigated in a study by Mughal and Schneider(2019) for Pakistan The authors found out, that, the literature may have mixed views in this regard but the effect might differ across various economies owing to the economic structure both in informal and formal sectors. For example Loayza (1996) in his growth model concluded that in economies where the statutory tax burden is larger than the optimal tax burden and the implementation of obedience is too weak, the increase of the relative size of informal economy generates a reduction of economic growth. While on the other hand shadow economy stimulates the economic activity by giving jobs to the unemployed and providing services in the far-flung areas of an economy where the official sector has not yet reached. Schneider and Hametner (2007) for Columbia and Kemal (2007) for Pakistan and Dell' Anno (2008) for Latin American Countries found a positive relation between the GDP growth and shadow economy. Therefore, we summarize our hypothesis: Increase in shadow economy may have a positive or negative effect on the growth of official economy.

Although the informal sector may have a positive or negative impact, yet it would be interesting to differentiate between long and short run impact of informal sector on the official one. By using ARDL model we can have long and short run estimates of shadow economy on the economic growth. This is one of the novelties in our research paper for which the authors have found no evidence in past literature. The empirical analysis is carried out by using a log-log model with Log of GDP per capita as the dependent variable and log of shadow economy (as percentage of GDP) as exogenous variable along with other control variables for the yearly data from 1973-2015. All the variables have been tested for Unit roots by using Dicky Fuller tests to make sure that none of the variables are I(2), as already discussed; ARDL can only have I(0) and I(1) variables. Akaike Information Criteria has been used to check for the optimal number of lags to be employed in the model. The following model is estimated:

$\triangle$ LnGDPPC $_{t}=\beta_{0}+\beta_{1}$ LnGDPPC $_{t-1}+\beta_{2}$ LnTINVPC $_{t-1}+\beta_{3}$ LnDEVHEXP $_{t-1}+\beta_{4}$ LnTVIENROLL $_{t-1}+\beta_{5}$ LnUNIENROLL $_{t-1}$

$+\beta_{5}$ LnINFL $_{t-1}+\beta_{6}$ LnSE $_{t-1}+\sum_{i=1}^{n} \gamma_{1 i} \Delta$ LnTINVPC $_{t-i}+\sum_{i=0}^{n} \gamma_{2 i} \Delta$ LnDEVHEXP $_{t-i}+\sum_{i=0}^{n} \gamma_{3 i} \Delta$ LnTVIENROLL $_{t-i}$

$+\sum_{i=0}^{n} \gamma_{4 i} \Delta \operatorname{LnUNIENROLL_{t-i}}+\sum_{i=0}^{n} \gamma_{5 i} \Delta \operatorname{LnINFL~}_{t-i}+\sum_{i=0}^{n} \gamma_{6 i} \Delta \operatorname{LnSE} E_{t-i}+\mu_{t}$

where

- GDPPC is GDP per capita as the dependent variable

- TINVPC is Total Investment per Capita

25 Section 6 B closely follows Mughal and Schneider (2019). The authors thank Khurrum Mughal for the permission to present their results. 
- DEVHEXP is Development expenditure in health sector

- TVIENROLL is enrollment in Technical and Vocational Institutes

- UNIENROLL is enrollment in Universities

- INFL is Rate of Inflation

- $\mathrm{SE}$ is the Shadow Economy as Percentage of GDP, own estimates.

All the variables appear in log form. The variables TINVPC, DEVHEXP, TVIENROLL, and UNIENROLL are expected to have a positive sign while INFL is expected to have negative effect on economic growth. The error correction term (Adjustment Term) is expected to have a negative significant sign. As already discussed, due to varying effects of shadow economy on the official sector, we might expect a positive or negative sign with the variable.

The results are placed at Table 8. All the variables appear with expected signs in short and long run except UNIENROLL, which is not statistically significant. In long run Total Investment per capita, Technical \& Vocational Institute Enrollment and Shadow economy as percentage of GDP have significant impacts. All these variables are significant at $1 \%$ level.

The short run results are also as expected. The most interesting part is that shadow economy has significant negative impact in the short run, which is different from long run effect. The shadow sector is a burden to the economy owing to tax evasion. This results into greater tax burden in the official sector hence a negative impact. The positive impact of shadow economy on economic growth in long run depicts the situation that it is a safe haven for poor population, which is highly likely in a developing country like Pakistan with growing population. Many rural areas are deprived of basic facilities coupled with high unemployment rate, which as seen in the estimations section was causing an increased demand for currency. Hence it is evident that the officially unemployed have found means to earn income while staying hidden from the government documentation. Hence, tax evasion and sales tax skimming might be a major part of this positive impact. Additionally with excessive government control in the economy, the bureaucratic power itself might drive people towards alternate means to achieve a given legal right. The positive impact of shadow sector is further authenticated by the recent events in 2015-16, when owing to increase in Bank withholding tax rates on tax filers and non-filers, many businessmen went on strikes against the Government. This clearly shows that tax evasion is from the productive sector of the society as well. Further if we consider the factor of intensity of regulations and control that increases bureaucratic power, it is a possibility that absence of such formalities may bring efficiency in business processes in the unofficial sector. Still it cannot be ignored that the hidden sector might also consist of illegal activities, and hence an increase in shadow economy might also contain a part of increase in illegal activities.

Table 9 gives the Bounds test statistic for cointegration while Table 10 below presents diagnostic test statistics for the above results:

Since the F-statistic of 7.584 in Table 9 is above the upper bound critical vale, there is long run cointegration among the variables. The Breusch-Godfrey LM test for autocorrelation and BreuschPagan/Cook-Weisberg test for heteroskedasticity clearly show that there no is problem of heteroskedasticity or serial correlation in the model, since we cannot reject the null hypothesis in each case. The CUSUM and CUSUM squared graphs also confirm stability of the model and are placed at Annex A. Based on the above model Log run normalized equation is: 
LnGDPPC $_{t}=4.428+1.054$ LnTINVPC +0.123 LnDEVHEXP +0.395 LnTVIENROLL 0.024 LnUNIENROLL -0.048 LnINFL + 0.573 LnSE

The above equation shows that a 1 percentage increase in SE would lead to 0.573 percentage increase in GDP per Capita. In order to empirically determine the relative and absolute influence of the shadow economy on official sector, for the study period, simulations are carried out. By using a dynamic simulation, the difference between official and theoretical real GDP per capita can be determined. Based on our estimates in table 8; shadow economy has positively and negatively contributed to GDP per capita in long and short runs respectively, hence by multiplying yearly variation in shadow economy with its estimated long run and short run coefficients and then subtracting long run result and adding short run result from the official recorded GDP per capita gives us the influence of Shadow Economy on the official economy of Pakistan, i.e. "What the official GDP per capita had been if the Shadow Economy had not been there?". The simulation results are shown in Figure 5. The figure consists of three columns, the official GDP per capita, long run effect of Shadow Sector, and the last column is one where the short run effects are also accounted for by adding back the negative influence of shadow economy in the short run. .

Figure above clearly shows that when the influence of Shadow Economy is removed using the estimated coefficient, the officially published figures are distorted, hence showing true picture of GDP per capita. Since the shadow economy has had positive effect on it in the Long run, therefore, if there had been no shadow economy the actual GDP per capita would have been lower. The same is presented in the table 11 below for some years.

\section{Summary AND CONCLUSIONS}

Using the multiple indicator-multiple cause (MIMIC) approach, this paper generates a novel global database by estimating the size of the shadow economy for 157 countries over 1991 to 2017 . The results suggest that the OECD countries are by far the lowest $\mathrm{w} . .$. values below $20 \%$ of off official GDP and the shadow economy is larger in Latin America and Sub-Saharan Africa, averaging almost 38 and 39 percent of GDP, respectively. The average over all countries and over 1991 to 2017 is $30.9 \%$. What is really remarkable, that the average decline of the shadow economy from 1991 to 2017 is 6.8 percentage points. The shadow economy is particularly large in countries such as Bolivia (Georgia) with 62.9 (61.7) percent of GDP, and low in countries such as Switzerland (United States) with 6.4 (7.6) percent of GDP, on average. Robustness tests include the use of satellite data on night lights intensity as a proxy for the size of countries' economies and the comparison of the results with 23 countries national statistical offices' measures of informality (discrepancy method used) demonstrate stable and similar results.

Additionally we investigated the interaction of the shadow economy with the official one. We come to the conclusion, that theoretically the effect of the shadow economy on the official one and vice versa is open. For an empirical investigation we used the paper by Mughal and Schneider (2019) for Pakistan over the period 1976 to 2015 . The results are, that in the short run the shadow economy has a negative impact on the official one and a positive one in the long run. However these are preliminary results where further investigations are needed to test the robustness of these findings. 
We conclude:

(1) Size of the shadow economy is quite large in some regions (LAC and SSA).

(2) Sizable heterogeneity within regions.

(3) Informal sector acts as a safety net.

(4) Informal sector has low productivity and keeps productivity low in a vicious cycle.

(5) A balanced approach is needed for transitioning from the informal to the formal sector.

(6) Key policy recommendations to formalize the informal sector:

(i) Improve Governance, a necessary condition.

(ii) Enhance Doing Business and Competitiveness Indicators, focusing on the indicators where the gap is largest compared to countries with smaller informal sectors.

(iii) Financial inclusion (fintech)

Finally we argue:

In every country the government faces the challenge to undertake policy measures which reduce a shadow economy and tax evasion.

However, the crucial question is: "Is this a blessing or a curse?"

Answers:

(1) If one assumes, that roughly $50 \%$ of all shadow economy activities complement those of the official sector (i.e. those goods would not be produced in the official sector) the development of the total (official + shadow economy) GDP is always higher than the "pure" official one.

(2) A decline of the shadow economy will only increase the total welfare in every country if the policy maker succeeds in transferring a shadow economic activity into the official economy.

(3) Therefore, a policy maker has to favor and choose such policy measures that strongly increase the incentives to transfer the production from the shadow (black) to the official sector.

Only then the decline of the shadow economy will be a blessing for the whole economy. 


\section{REFERENCES}

Alm, James \& Abel Embaye, (2013), Using Dynamic Panel Methods to Estimate Shadow Economies Around the World, 1984-2006, Working Papers 1303, Tulane University, Department of Economics.

Abdih, Y. and Medina, L. (2013), Measuring the Informal Economy in the Caucasus and Central Asia, International Monetary Fund, WP/13/137.

Besozzi, C., (2001), Illegal, legal - egal?: llegal, legal - egal? Zur Entstehung, Struktur und Auswirkungen illegaler Märkte, Bern: Haupt Verlag.

Breusch, V. (2016), Estimating the Underground Economy using MIMIC models, Journal of Tax Administration, Vol. 2, No. 1.

Boeschoten, W.C. and M.M.G. Fase (1984), The Volume of Payments and the Informal Economy in the Netherlands 1965-1982, M. Nijhoff, Dordrecht.

Buehn, A., Karmann, A. and Schneider, F. (2009), Shadow Economy and Do-it-Yourself Activities: The German Case, Journal of Institutional and Theoretical Economics (JITE) 165/4, 701-722.

Buehn, A. and Schneider, F.(2012), Shadow Economies around the World: novel insights, accepted knowledge, and new estimates; International Tax and Public Finance 19/1, ; pp.139- - 171.

Cagan, P. (1958), The demand for currency relative to the total money supply, Journal of Political Economy, 66, pp. 302-328.

Contini, B. (1981), Labor market segmentation and the development of the parallel economy: the Italian experience, Oxford Economic Papers, 33, pp. 401-412.

Del Boca, D. (1981), Parallel economy and allocation of time, Micros (Quarterly Journal of Microeconomics), 4, pp. 13-18.

Del Boca, D. and F. Forte (1982), Recent empirical surveys and theoretical interpretations of the parallel economy in Italy, in: V. Tanzi (ed.), The Underground Economy in the United States and Abroad, Lexington Books, Lexington, MA, pp. 160-178.

Dell'Anno R. (2007), The Shadow Economy in Portugal: An Analysis with the MIMIC Approach, Journal of Applied Economics, 10, pp. 253-277.

Dell'Anno, Roberto (2008) "What is the Relationship between Unofficial and Official Economy? An analysis in Latin American Countries", European Journal of Economics, Finance and Administrative Sciences, Issue 12 (2008): 185-203.

Dell'Anno, R. and F. Schneider (2009), A complex approach to estimate shadow economy: the structural equation modelling, in M. Faggnini and T. Looks (eds.), Coping with the Complexity of Economics, Springer, Berlin, pp. 110-30.

Dreher, A. and F. Schneider (2009), Corruption and the Shadow Economy: An Empirical Analysis, Public Choice, 144/2, pp. 215-277.

Dreher, A., Kotsogiannis, C. and S. McCorriston (2009), How Do Institutions Affect Corruption and the Shadow Economy?, International Tax and Public Finance, 16/4, pp. 773-796.

Enste, D. and Schneider, F., (2006), Umfang und Entwicklung der Schattenwirtschaft in 145 Ländern, in: Schneider F. und Enste, D. (eds), Jahrbuch Schattenwirtschaft 2006/07:Zum Spannungsfeld von Politik und Ökonomie, Berlin LIT Verlag, pp 55-80. 
Feige, E. (1979), How Big is the Irregular Economy?, Challenge, 22(5), pp. 5-13.

Feige, E.L. (1996), Overseas holdings of U.S. currency and the underground economy. In: Pozo, S. (Ed.), Exploring the Underground Economy. W.E. Upjohn Institute for Employment Research, Kalamazoo, MI, pp. 5-62.

Feige, E.L. (2016a), Reflections on the Meaning and Measurement of Unobserved Economies: What do we really know about the "Shadow Economy"?, Journal of Tax Administration, Vol 2:2.

Feige, Edward L. (2016b), Professor Schneider's Shadow Economy (SSE): What Do We Really Know? A Rejoinder, Journal of Tax Administration, 2/2.

Feld, L.P. and B.S. Frey (2007), Tax Compliance as the Result of a Psychological Tax Contract: The Role of Incentives and Responsive Regulation, Law and Policy, 29/1, pp. 102-120.

Feld, L.P. and C. Larsen (2005), Black Activities in Germany in 2001 and 2004: A Comparison Based on Survey Data, Study no. 12, Copenhagen: Rockwool Foundation Research Unit.

Feld, L.P. and C. Larsen (2009), Undeclared Work in Germany 2001-2007 - Impact of Deterrence, Tax Policy, and Social Norms: An Analysis Based on Survey Data, Springer, Berlin.

Feld, L. and Schneider, F. (2010). Survey on the Shadow Economy and Undeclared Earnings in OECD Countries, German Economic Review, 11(2), 109-149.

Feld, L.P. and Schneider, F. (2016), " Reply to Gebhard Kirchgaessner", German Economic Review, 18/1, pp.112-117.

Fleming, M., Roman, J., Farrell, G., (2000), The Shadow Economy. Journal of International Affairs, 53(2), 387-409.

Gerxhani, K. (2003), The informal sector in developed and less-developed countries: A literature survey, Public Choice, 114/3-4, pp. 295-318.

Giles, D.E.A. (1999a), Measuring the Hidden Economy: Implications for Econometric Modelling, Economic Journal, 109/3, pp. 370-380.

Gutmann, P.M. (1977), The subterranean economy, Financial Analysts Journal, 34/1, pp. 24- 27.

Gyomai, G., van de Ven, P. (2014), The non-observed economy in the system of national accounts, Statistics Brief No. 18.

Hashimzade, N. and Heady C. (2016), Reflections on the meaning and measurement of unobserved economies: An editorial comment, Journal of Tax Administration 2:2.

Hassan, M. and Scheider, F. (2016), Size and development of the shadow economies of 157 worldwide countries: Updated and new measures from 1999 to 2013, Journal of Global Economics 4:3.

Henderson, V. J., Storeygard, A. and Weil, D. N. (2012), Measuring Economic Growth from Outer Space, American Economic Review, 102(2): 994-1028.

Isachsen, A.J. and S. Strøm (1985), The Size and Growth of the Hidden Economy in Norway, Review of Income and Wealth, 31/1, pp. 21-38.

Johnson, S., Kaufmann, D. and A. Shleifer (1997), The unofficial economy in transition, Brookings Papers on Economic Activity, Fall, Washington D.C. 
Johnson, S., Kaufmann, D. \& Zoido-Lobatón, P. (1998a). Regulatory Discretion and the Unofficial Economy, The American Economic Review, 88(2): 387-392.

Johnson, S., Kaufmann D. and P. Zoido-Lobatón (1998b), Corruption, Public Finances and the Unofficial Economy, World Bank Policy Research Working Paper Series No. 2169, The World Bank, Washington, D.C.

Kemal M. Ali, (2007). "A Fresh Assessment of Underground Economy and Tax Evasion in Pakistan: Causes, Consequences and Linkages with the Formal Economy", Pakistan Institute of Development Economics Working Paper 2007: 13, Islamabad, Pakistan.

Kirchgässner, G. (1983), Size and development of the West German shadow economy, 1955-1980, Zeitschrift für die Gesamte Staatswissenschaft, 139, pp. 197-214.

Kirchgaessner, G. (2016), "On ESTIMATING THE size of the SHADOW economy", German Economic Review 18/1, pp. 99-111.

Kucera, D. and L. Roncolato (2008), Informal Employment: Two Contested Policy Issues, International Labor Review, 147/3, pp. 321-348.

Langfeldt, E. (1984), The unobserved economy in the Federal Republic of Germany, in: Feige, E.L. (ed.), The Unobserved Economy, Cambridge University Press, Cambridge, UK, pp. 236-260.

Loayza, N. V. (1996), The economics of the informal sector: a simple model and some empirical evidence from Latin America, Carnegie-Rochester Conference Series on Public Policy, 45, pp. $129-162$.

Lubell, H., (1991), The Informal Sector in the 1980s and 1990s. Paris: OECD Publishing.

MacAfee, K. (1980), A glimpse of the hidden economy in the national accounts, Economic Trends, 136, pp. 81-87.

Medina, L., A. Jonelis, and M. Cangul, (2017), The Informal Economy in Sub-Saharan Africa: Size and Determinants, International Monetary Fund, WP/17/156.

Medina, L. and Schneider, F. (2018), Shadow economies around the world: What did we learn over the last 20 years?, IMF Working Paper WP018, IMF, Washington DC, USA

McGee, R.T., Feige, E.L., (1989), Policy Illusion, Macroeconomic Instability, and the Unrecorded Economy. In E.L. Feige (ed.), The Underground Economies: Tax Evasion and Information Distortion. Cambridge: Cambridge University Press, pp. 81-

Mogensen, G.V., Kvist, H.K., Kfrmendi, E. and S. Pedersen (1995), The Shadow Economy in Denmark 1994: Measurement and Results, Study no. 3, The Rockwool Foundation Research Unit, Copenhagen.

Mughal, Khurrum and Schneider, (2019), "How the Informal Sector Affects the Formal Economy in Pakistan? A lesson for Developing Countries" Discussion Paper; University of Linz, Linz, Austria; , revised version, a first one (2018) appeared in: https://mpra.ub.uni-muenchen.de/87087/.

Portes, A. (1996), The informal economy, in: Pozo, S. (ed.), Exploring the Underground Economy, W.E. Upjohn Institute for Employment Research, Kalamazoo, pp. 147-165.

Schneider, F. (2005), Shadow economies around the world: what do we really know?, European Journal of Political Economy, 21(4), pp. 598-642. 
Schneider, F. (2010), The Influence of Public Institutions on the Shadow Economy: An Empirical Investigation for OECD Countries, European Journal of Law and Economics, 6/3, pp. 441-468.

Schneider, F. (ed.) (2011), Handbook on the Shadow Economy, Edward Elgar, Cheltenham.

Schneider, F. (2016), Comment on Feige's Paper, Reflections on the Meaning and Measurement of Unobserved Economies: What do we really know about the "Shadow Economy?", Journal of Tax Administration, Vol 2:2, pp. 82-92.

Schneider, Friedrich (2017), Estimating a Shadow Economy: Results, Methods, Problems, and Open Questions, De Gruyter Open, Open Economics 2017/1, pp. 1-29.

Schneider, F. and D. Enste (2000), Shadow economies: size, causes and consequences, Journal of Economic Literature, 38/1, pp. 77-114.

Schneider, F. and D. Enste (2002), The Shadow Economy: Theoretical Approaches, Empirical Studies, and Political Implications, Cambridge University Press, Cambridge (UK).

Schneider, F., Hametner, B.(2014), The Shadow Economy in Columbia: Size and Effects on Economic Growth, Peace Economics, Peace Science and Public Policy, 20(2), 293-325.

Tanzi, V. (1999), Uses and Abuses of Estimates of the Underground Economy, Economic Journal, 109/3, pp. 338-347.

Tanzi, V. (1980), The underground economy in the United States: estimates and implications, Banca Nazionale del Lavoro, 135, pp. 427-453.

Tanzi, V. (1983), The underground economy in the United States: annual estimates, 1930-1980, IMF Staff Papers, 30, pp. 283-305.

Teobaldelli, D. (2011), Federalism and the Shadow Economy, Public Choice, 146/3, pp. 269-269.

Thomas, J. J. (1992), Informal Economic Activity, LSE, Handbooks in Economics, Harvester Wheatsheaf, London.

Torgler, B. and F. Schneider (2009), The Impact of Tax Morale and Institutional Quality on the Shadow Economy, Journal of Economic Psychology, 30/3, pp. 228-245.

Vuletin, G.J. (2008), Measuring the Informal Economy in Latin America and the Caribbean, International Monetary Fund, Working Paper No. 08/102.

Williams, C. C. and Schneider, F. (2016). Measuring the Global Shadow Economy: The Prevalence of Informal Work and Labour. Edward Elgar Publishing, UK.

Witte, A.D. (1987), The nature and extent of unreported activity: a survey concentrating on a recent US research, in: Alessandrini, S. and B. Dallago (eds.), The Unofficial Economy: Consequences and Perspectives in Different Economic Systems, Gower, Aldershot.

Yoo, T. and Hyun, J. K. (1998), International Comparison of the Black Economy: Empirical Evidence Using Micro-Level Data, paper presented at 1998 Congress of Int. Institute Public Finance, Cordoba, Argentina.

Zellner, A. (1970). Estimation of Regression Relationships Containing Unobservable Independent Variables. International Economic Review, 11(3), 441-454. 


\section{TABLES AND Figures}

Table 1. MIMIC Model Estimation Results: 1991-2017, All Countries

\begin{tabular}{|c|c|c|c|c|c|c|}
\hline & (1) & $(2)$ & (3) & (4) & (5) & (6) \\
\hline \multicolumn{7}{|l|}{ Causes } \\
\hline Trade Openness & $-0.077 * * *$ & $-0.074 * * *$ & $-0.097 * * *$ & $-0.063 * *$ & $-0.062 * *$ & $-0.097 * * *$ \\
\hline GDP Per Capita & $-0.299 * * *$ & $-0.304 * * *$ & $-0.347 * * *$ & $-0.244 * * *$ & $-0.256 * * *$ & $-0.290 * * *$ \\
\hline Unemployment Rate & 0.002 & 0.004 & 0.026 & -0.001 & 0.003 & $0.044 *$ \\
\hline Size of Government & $0.110^{* * *}$ & $0.115^{* * *}$ & $0.140 * * *$ & & & \\
\hline Fiscal Freedom & & & & $-0.097 * * *$ & $-0.101 * * *$ & $-0.105^{* * *}$ \\
\hline Rule of Law & $-0.043^{*}$ & & & $-0.057 * *$ & & \\
\hline Control of Corruption & & $-0.067 * * *$ & & & $-0.062 * * *$ & \\
\hline Government Stability & & & $-0.045^{*}$ & & & -0.038 \\
\hline \multicolumn{7}{|l|}{ Indicators } \\
\hline Currency & 1 & 1 & 1 & 1 & 1 & 1 \\
\hline Labor Force Participation Rate & $-0.523 * * *$ & $-0.525 * * *$ & $-0.410 * * *$ & $-0.529 * * *$ & $-0.523 * * *$ & $-0.389 * * *$ \\
\hline GDP Per Capita Growth & -0.051 & -0.100 & $-0.241 * * *$ & 0.088 & 0.048 & $-0.097 *$ \\
\hline \multicolumn{7}{|l|}{ Statistical Tests } \\
\hline RMSEA & 0.061 & 0.052 & 0.057 & 0.051 & 0.043 & 0.048 \\
\hline Chi-square (model vs. saturated) & 87.902 & 66.165 & 89.216 & 61.262 & 46.931 & 58.653 \\
\hline Chi-square (baseline vs. saturated) & 419.447 & 401.916 & 582.586 & 340.457 & 326.345 & 432.786 \\
\hline Observations & 2106 & 2100 & 2450 & 1980 & 1979 & 2109 \\
\hline Countries & 150 & 150 & 122 & 147 & 147 & 120 \\
\hline
\end{tabular}

Source: Own calculations.

Note: $* * * \mathrm{p}<0.01, * * \mathrm{p}<0.05, * \mathrm{p}<0.1$

Table 2. MIMIC Model Estimation Results: 1991-2017, Developing Countries
(1)
(2)
(3)
(4)
(5)
(6)

\begin{tabular}{|c|c|c|c|c|c|c|}
\hline \multicolumn{7}{|l|}{ Causes } \\
\hline Trade Openness & $-0.064 * *$ & $-0.063 * *$ & $-0.084 * * *$ & $-0.056^{*}$ & $-0.053^{*}$ & $-0.088 * * *$ \\
\hline GDP Per Capita & $-0.301 * * *$ & $-0.301 * * *$ & $-0.339 * * *$ & $-0.256 * * *$ & $-0.258 * * *$ & $-0.295^{* * *}$ \\
\hline Unemployment Rate & -0.002 & -0.030 & -0.003 & -0.037 & -0.037 & 0.017 \\
\hline Size of Government & $0.149 * * *$ & $0.146 * * *$ & $0.171 * * *$ & & & \\
\hline Fiscal Freedom & & & & $-0.088 * * *$ & $-0.088 * * *$ & $-0.089 * * *$ \\
\hline Rule of Law & -0.001 & & & -0.010 & & \\
\hline Control of Corruption & & $-0.042 *$ & & & -0.039 & \\
\hline Government Stability & & & $-0.059 * *$ & & & $-0.055^{*}$ \\
\hline \multicolumn{7}{|l|}{ Indicators } \\
\hline Currency & 1 & 1 & 1 & 1 & 1 & 1 \\
\hline Labor Force Participation Rate & $-0.439 * * *$ & $-0.432 * * *$ & $-0.337 * * *$ & $-0.500 * * *$ & $-0.489 * * *$ & $-0.272 * * *$ \\
\hline GDP Per Capita Growth & $-0.243 * * *$ & $-0.250 * * *$ & $-0.335 * * *$ & $-0.144 *$ & $-0.158 *$ & $-0.199 * * *$ \\
\hline \multicolumn{7}{|l|}{ Statistical Tests } \\
\hline RMSEA & 0.051 & 0.051 & 0.057 & 0.051 & 0.043 & 0.048 \\
\hline Chi-square (model vs. saturated) & 46.76 & 46.948 & 63.393 & 40.436 & 40.557 & 49.655 \\
\hline Chi-square (baseline vs. saturated) & 250.120 & 246.883 & 377.723 & 189.131 & 187.305 & 257.792 \\
\hline Observations & 1441 & 1435 & 1728 & 1349 & 1348 & 1462 \\
\hline Countries & 102 & 102 & 82 & 99 & 99 & 80 \\
\hline
\end{tabular}

Source: Own calculations.

Note: *** $\mathrm{p}<0.01, * * \mathrm{p}<0.05, * \mathrm{p}<0.1$ 
Table 3. MIMIC Model Estimation Results: 1991-2017, Advanced Countries

\begin{tabular}{|c|c|c|c|c|c|c|}
\hline & (1) & (2) & (3) & (4) & (5) & (6) \\
\hline \multicolumn{7}{|l|}{ Causes } \\
\hline Trade Openness & -0.030 & 0.015 & $-0.088 *$ & -0.016 & 0.024 & -0.043 \\
\hline GDP Per Capita & $-0.224 * * *$ & $-0.301 * * *$ & $-0.303 * * *$ & -0.121 & $-0.185^{* *}$ & $-0.168 * * *$ \\
\hline Unemployment Rate & $0.137^{*}$ & $0.114 *$ & $0.106 * * *$ & $0.119 *$ & $0.128 * *$ & $0.147 * * *$ \\
\hline Size of Government & -0.047 & -0.022 & -0.053 & & & \\
\hline Fiscal Freedom & & & & $-0.192 * * *$ & $-0.200 * * *$ & $-0.122 * * *$ \\
\hline Rule of Law & $-0.110 *$ & & & $-0.107 *$ & & \\
\hline Control of Corruption & & $-0.156 * * *$ & & & $-0.153 * * *$ & \\
\hline Government Stability & & & $-0.071^{*}$ & & & -0.029 \\
\hline \multicolumn{7}{|l|}{ Indicators } \\
\hline Currency & 1 & 1 & 1 & 1 & 1 & 1 \\
\hline Labor Force Participation Rate & $-0.863 * * *$ & $-0.834 * * *$ & $-1.150 * * *$ & $-0.816 * * *$ & $-0.879 * * *$ & $-1.351 * * *$ \\
\hline GDP Per Capita Growth & -0.06 & -0.267 & -0.134 & 0.058 & -0.198 & -0.329 \\
\hline \multicolumn{7}{|l|}{ Statistical Tests } \\
\hline RMSEA & 0.132 & 0.121 & 0.115 & 0.127 & 0.109 & 0.095 \\
\hline Chi-square (model vs. saturated) & 61.556 & 53.68 & 67.885 & 57.713 & 45.355 & 44.581 \\
\hline Chi-square (baseline vs. saturated) & 132.743 & 133.402 & 234.006 & 140.224 & 145.208 & 177.878 \\
\hline Observations & 296 & 296 & 439 & 296 & 296 & 382 \\
\hline Countries & 27 & 27 & 27 & 27 & 27 & 27 \\
\hline
\end{tabular}

Source: Own calculations.

Note: $* * * \mathrm{p}<0.01, * * \mathrm{p}<0.05, * \mathrm{p}<0.1$ 
Table 4. Summary statistics of the shadow economy of 157 countries, 1991-17

\begin{tabular}{|c|c|c|c|c|c|c|}
\hline Country & ISO & Average & $\begin{array}{l}\text { Standard } \\
\text { Deviation }\end{array}$ & Median & Min. & Max. \\
\hline Albania & ALB & 32.4 & 4.6 & 32.4 & 27.0 & 42.1 \\
\hline Algeria & DZA & 32.3 & 3.7 & 32.7 & 25.5 & 37.9 \\
\hline Angola & AGO & 44.5 & 5.9 & 45.5 & 35.2 & 52.7 \\
\hline Argentina & ARG & 24.8 & 2.0 & 25.0 & 20.9 & 28.5 \\
\hline Armenia & ARM & 42.2 & 4.3 & 43.2 & 34.5 & 48.7 \\
\hline Australia & AUS & 12.2 & 1.6 & 12.2 & 9.4 & 15.2 \\
\hline Austria & AUT & 7.9 & 0.9 & 7.8 & 6.4 & 9.1 \\
\hline Azerbaijan, Rep. of & $\overline{\text { AZE }}$ & 53.4 & 6.7 & 54.6 & 42.4 & 64.9 \\
\hline Bahamas, The & BHS & 28.5 & 3.0 & 27.8 & 24.6 & 34.2 \\
\hline Bahrain, Kingdom of & BHR & 17.3 & 2.3 & 16.9 & 13.9 & 20.3 \\
\hline Bangladesh & BGD & 33.1 & 3.6 & 35.0 & 25.9 & 36.9 \\
\hline Belarus & BLR & 43.9 & 6.3 & 46.6 & 33.1 & 52.9 \\
\hline Belgium & BEL & 18.4 & 1.8 & 18.3 & 15.5 & 20.9 \\
\hline Belize & $\overline{B L Z}$ & 46.2 & 4.4 & 45.0 & 41.0 & 56.9 \\
\hline Benin & BEN & 49.4 & 4.0 & 50.0 & 40.0 & 56.2 \\
\hline Bhutan & BTN & 25.6 & 3.3 & 26.5 & 19.0 & 29.6 \\
\hline Bolivia & BOL & 62.9 & 6.3 & 65.1 & 50.7 & 70.5 \\
\hline $\begin{array}{l}\text { Bosnia \& } \\
\text { Herzegovina }\end{array}$ & BIH & 32.4 & 2.9 & 31.9 & 26.9 & 39.5 \\
\hline Botswana & BWA & 29.8 & 4.4 & 29.1 & 22.6 & 35.3 \\
\hline Brazil & BRA & 36.7 & 4.3 & 38.5 & 28.2 & 41.5 \\
\hline Brunei Darussalam & BRN & 28.8 & 3.3 & 30.1 & 21.5 & 32.9 \\
\hline Bulgaria & BGR & 29.9 & 4.5 & 30.8 & 22.9 & 35.3 \\
\hline Burkina Faso & BFA & 37.4 & 4.6 & 38.1 & 29.3 & 43.6 \\
\hline Burundi & BDI & 37.0 & 2.5 & 36.6 & 32.7 & 41.5 \\
\hline Cambodia & KHM & 49.4 & 4.4 & 49.6 & 40.1 & 57.9 \\
\hline Cameroon & CMR & 30.9 & 2.8 & 31.1 & 26.4 & 35.0 \\
\hline Canada & CAN & 13.3 & 1.6 & 13.2 & 11.1 & 16.6 \\
\hline Cape Verde & CPV & 33.3 & 5.1 & 34.9 & 26.1 & 41.3 \\
\hline Central African Rep. & CAF & 38.2 & 3.0 & 38.8 & 32.8 & 43.0 \\
\hline Chad & TCD & 41.7 & 4.5 & 40.8 & 34.4 & 47.4 \\
\hline Chile & CHL & 17.1 & 1.8 & 17.2 & 14.1 & 19.3 \\
\hline $\begin{array}{l}\text { China,P.R.: } \\
\text { Mainland }\end{array}$ & CHN & 13.9 & 1.8 & 14.1 & 11.0 & 16.5 \\
\hline Colombia & COL & 33.5 & 4.8 & 36.1 & 25.2 & 40.1 \\
\hline Comoros & COM & 32.7 & 4.4 & 33.4 & 25.6 & 39.6 \\
\hline Congo, Dem. Rep. of & COD & 49.7 & 4.8 & 49.0 & 41.7 & 56.5 \\
\hline Congo, Republic of & COG & 45.9 & 6.2 & 46.5 & 35.1 & 56.4 \\
\hline Costa Rica & CRI & 23.5 & 1.2 & 23.7 & 21.2 & 26.0 \\
\hline
\end{tabular}


Table 4. Summary statistics of the shadow economy of 157 countries, 1991-17 (cont.)

\begin{tabular}{|c|c|c|c|c|c|c|}
\hline Country & ISO & Average & $\begin{array}{l}\text { Standard } \\
\text { Deviation }\end{array}$ & Median & Min. & Max. \\
\hline Côte d'Ivoire & CIV & 38.5 & 4.0 & 39.3 & 31.7 & 44.1 \\
\hline Croatia & HRV & 27.5 & 3.9 & 26.6 & 21.6 & 34.4 \\
\hline Cyprus & CYP & 28.2 & 2.9 & 27.5 & 23.1 & 34.5 \\
\hline Czech Republic & CZE & 15.0 & 2.3 & 15.9 & 11.7 & 18.6 \\
\hline Denmark & DNK & 13.4 & 1.5 & 13.3 & 10.9 & 15.8 \\
\hline Dominican Republic & DOM & 31.1 & 1.9 & 31.7 & 27.5 & 34.7 \\
\hline Ecuador & $\mathbf{E C U}$ & 33.6 & 2.7 & 34.1 & 29.2 & 37.5 \\
\hline Egypt & EGY & 33.8 & 2.8 & 35.1 & 29.9 & 37.6 \\
\hline El Salvador & SLV & 44.2 & 3.7 & 44.6 & 38.6 & 51.3 \\
\hline Equatorial Guinea & GNQ & 31.6 & 3.8 & 32.8 & 23.9 & 36.2 \\
\hline Estonia & EST & 24.1 & 3.3 & 23.7 & 19.3 & 29.1 \\
\hline Ethiopia & ETH & 34.5 & 4.2 & 35.6 & 26.9 & 40.3 \\
\hline Fiji & FJI & 29.7 & 3.4 & 30.0 & 23.4 & 35.2 \\
\hline Finland & FIN & 12.1 & 1.4 & 11.5 & 9.7 & 14.7 \\
\hline France & FRA & 12.9 & 1.4 & 12.6 & 10.1 & 15.3 \\
\hline Gabon & GAB & 51.2 & 4.1 & 51.8 & 42.3 & 57.8 \\
\hline Gambia, The & GMB & 45.0 & 1.8 & 45.1 & 41.6 & 48.9 \\
\hline Georgia & GEO & 61.7 & 6.1 & 62.8 & 50.4 & 69.1 \\
\hline Germany & DEU & 11.4 & 1.5 & 11.2 & 8.7 & 13.3 \\
\hline Ghana & GHA & 41.0 & 5.2 & 42.5 & 31.8 & 48.3 \\
\hline Greece & GRC & 24.9 & 2.1 & 25.3 & 19.7 & 27.7 \\
\hline Guatemala & GTM & 50.3 & 4.1 & 50.5 & 42.0 & 56.2 \\
\hline Guinea & GIN & 36.1 & 2.7 & 37.5 & 30.7 & 40.0 \\
\hline Guinea-Bissau & GNB & 34.8 & 4.0 & 36.8 & 26.9 & 40.2 \\
\hline Guyana & GUY & 30.3 & 3.2 & 31.5 & 24.5 & 34.8 \\
\hline Haiti & HTI & 53.8 & 4.8 & 54.7 & 46.7 & 62.7 \\
\hline Honduras & HND & 47.5 & 3.2 & 47.8 & 41.0 & 52.8 \\
\hline Hong Kong SAR & HKG & 15.0 & 1.7 & 15.4 & 11.8 & 17.1 \\
\hline Hungary & HUN & 23.5 & 3.5 & 22.6 & 18.9 & 30.1 \\
\hline Iceland & ISL & 13.4 & 1.3 & 13.9 & 10.8 & 15.0 \\
\hline India & IND & 23.6 & 3.2 & 24.0 & 18.5 & 27.8 \\
\hline Indonesia & IDN & 23.7 & 1.9 & 24.0 & 20.5 & 26.9 \\
\hline Iran, I.R. of & IRN & 17.1 & 2.3 & 17.0 & 13.2 & 20.5 \\
\hline Ireland & IRL & 12.8 & 1.8 & 12.6 & 9.5 & 15.7 \\
\hline Israel & ISR & 21.4 & 2.8 & 21.9 & 17.0 & 25.9 \\
\hline Italy & ITA & 21.8 & 2.2 & 21.2 & 18.1 & 26.2 \\
\hline Jamaica & JAM & 34.4 & 2.3 & 34.5 & 29.9 & 38.8 \\
\hline Japan & JPN & 11.3 & 1.0 & 11.5 & 9.2 & 13.0 \\
\hline Jordan & JOR & 17.3 & 2.2 & 17.7 & 14.1 & 19.9 \\
\hline
\end{tabular}


Table 4. Summary statistics of the shadow economy of 157 countries, 1991-17 (cont.)

\begin{tabular}{|c|c|c|c|c|c|c|}
\hline Country & ISO & Average & $\begin{array}{l}\text { Standard } \\
\text { Deviation }\end{array}$ & Median & Min. & Max. \\
\hline Kazakhstan & KAZ & 40.0 & 4.8 & 41.6 & 31.1 & 45.9 \\
\hline Kenya & KEN & 31.9 & 3.6 & 33.3 & 24.4 & 36.3 \\
\hline Korea, Republic of & KOR & 26.0 & 2.4 & 26.4 & 21.8 & 29.4 \\
\hline Kuwait & KWT & 18.6 & 2.2 & 19.2 & 14.5 & 22.5 \\
\hline Kyrgyz Republic & KGZ & 36.0 & 4.6 & 37.7 & 28.0 & 41.2 \\
\hline $\begin{array}{l}\text { Lao People's } \\
\text { Dem.Rep }\end{array}$ & LAO & 29.7 & 3.0 & 30.7 & 23.7 & 33.8 \\
\hline Latvia & LVA & 22.5 & 3.4 & 22.5 & 17.9 & 27.8 \\
\hline Lebanon & LBN & 32.0 & 3.4 & 32.5 & 27.1 & 37.2 \\
\hline Lesotho & LSO & 29.6 & 1.9 & 29.9 & 25.9 & 32.2 \\
\hline Liberia & LBR & 41.8 & 2.6 & 41.5 & 38.2 & 47.0 \\
\hline Libya & LBY & 34.2 & 4.6 & 36.3 & 22.5 & 39.4 \\
\hline Lithuania & LTU & 25.7 & 4.1 & 25.3 & 19.7 & 31.6 \\
\hline Luxembourg & LUX & 9.6 & 1.0 & 9.8 & 7.9 & 10.9 \\
\hline Madagascar & MDG & 39.1 & 1.7 & 39.2 & 34.5 & 42.4 \\
\hline Malawi & MWI & 35.8 & 3.4 & 34.9 & 29.7 & 43.4 \\
\hline Malaysia & MYS & 31.0 & 2.7 & 31.1 & 26.9 & 37.2 \\
\hline Maldives & MDV & 28.6 & 2.4 & 29.6 & 24.9 & 32.1 \\
\hline Mali & MLI & 37.3 & 3.6 & 37.9 & 32.2 & 44.6 \\
\hline Malta & MLT & 25.7 & 3.2 & 26.9 & 18.6 & 30.3 \\
\hline Mauritania & MRT & 32.8 & 3.3 & 32.9 & 27.2 & 38.2 \\
\hline Mauritius & MUS & 21.6 & 1.9 & 22.1 & 17.8 & 24.3 \\
\hline Mexico & MEX & 30.5 & 2.7 & 30.1 & 26.6 & 35.8 \\
\hline Moldova & MDA & 41.5 & 4.2 & 41.8 & 34.7 & 48.7 \\
\hline Mongolia & MNG & 17.2 & 1.9 & 17.5 & 14.0 & 20.8 \\
\hline Morocco & MAR & 33.6 & 3.4 & 34.3 & 28.3 & 38.8 \\
\hline Mozambique & MOZ & 38.0 & 4.2 & 39.2 & 30.0 & 46.4 \\
\hline Myanmar & MMR & 47.0 & 4.7 & 48.4 & 36.4 & 52.7 \\
\hline Namibia & NAM & 27.9 & 3.4 & 28.5 & 22.9 & 32.1 \\
\hline Nepal & NPL & 36.4 & 2.4 & 36.8 & 31.1 & 40.8 \\
\hline Netherlands & NLD & 9.9 & 1.0 & 9.8 & 8.4 & 11.5 \\
\hline New Zealand & NZL & 11.2 & 0.9 & 11.3 & 9.5 & 13.2 \\
\hline Nicaragua & NIC & 42.0 & 4.9 & 43.0 & 33.8 & 50.8 \\
\hline Niger & NER & 39.1 & 3.2 & 40.1 & 33.4 & 43.7 \\
\hline Nigeria & NGA & 56.8 & 4.4 & 57.8 & 47.6 & 64.0 \\
\hline Norway & NOR & 12.6 & 1.5 & 12.7 & 9.4 & 14.8 \\
\hline Oman & OMN & 17.7 & 2.6 & 18.4 & 12.6 & 20.7 \\
\hline Pakistan & PAK & 34.2 & 2.7 & 34.3 & 30.1 & 39.3 \\
\hline Papua New Guinea & PNG & 34.0 & 3.6 & 35.6 & 27.8 & 39.3 \\
\hline
\end{tabular}




\begin{tabular}{|c|c|c|c|c|c|c|}
\hline Paraguay & PRY & 35.2 & 2.9 & 35.6 & 30.7 & 39.8 \\
\hline Peru & PER & 53.5 & 5.8 & 56.6 & 43.6 & 60.0 \\
\hline Philippines & PHL & 40.8 & 3.7 & 41.0 & 34.9 & 45.8 \\
\hline Poland & POL & 24.4 & 3.5 & 25.3 & 19.4 & 29.9 \\
\hline Portugal & PRT & 19.7 & 2.0 & 20.0 & 16.1 & 22.5 \\
\hline Qatar & QAT & 17.8 & 2.8 & 17.8 & 13.1 & 22.0 \\
\hline Romania & ROM & 28.9 & 3.7 & 30.1 & 23.0 & 34.4 \\
\hline Russian Federation & RUS & 39.6 & 4.2 & 40.4 & 32.5 & 46.3 \\
\hline Rwanda & RWA & 34.8 & 4.4 & 36.5 & 27.7 & 40.7 \\
\hline Saudi Arabia & SAU & 16.3 & 2.3 & 16.8 & 12.2 & 19.4 \\
\hline Senegal & SEN & 42.1 & 3.0 & 43.2 & 36.8 & 46.3 \\
\hline Sierra Leone & SLE & 40.7 & 5.3 & 42.7 & 28.4 & 48.6 \\
\hline Singapore & SGP & 11.7 & 1.4 & 11.8 & 9.4 & 13.9 \\
\hline Slovak Republic & SVK & 15.8 & 2.4 & 15.3 & 12.6 & 19.8 \\
\hline Slovenia & SVN & 23.0 & 2.7 & 23.1 & 18.3 & 27.9 \\
\hline Solomon Islands & SLB & 30.7 & 3.8 & 30.8 & 24.5 & 36.1 \\
\hline South Africa & ZAF & 26.8 & 2.7 & 27.3 & 21.9 & 30.4 \\
\hline Spain & ESP & 22.2 & 2.1 & 21.4 & 18.6 & 26.4 \\
\hline Sri Lanka & LKA & 43.9 & 4.2 & 45.9 & 35.5 & 48.9 \\
\hline Suriname & SUR & 37.8 & 4.6 & 38.5 & 30.3 & 45.0 \\
\hline Swaziland & SWZ & 40.6 & 2.9 & 40.5 & 35.2 & 44.9 \\
\hline Sweden & SWE & 11.9 & 1.7 & 11.5 & 9.5 & 15.2 \\
\hline Switzerland & CHE & 6.4 & 0.9 & 6.6 & 5.1 & 7.6 \\
\hline Syrian Arab Republic & SYR & 19.3 & 1.2 & 19.3 & 16.1 & 21.7 \\
\hline $\begin{array}{l}\text { Taiwan Province of } \\
\text { China }\end{array}$ & TWN & 29.8 & 4.8 & 28.7 & 22.8 & 37.8 \\
\hline Tajikistan & TJK & 41.2 & 4.0 & 41.6 & 34.0 & 47.8 \\
\hline Tanzania & TZA & 56.0 & 6.3 & 57.7 & 45.4 & 67.0 \\
\hline Thailand & THA & 49.6 & 4.2 & 50.2 & 41.9 & 55.4 \\
\hline Togo & TGO & 33.4 & 3.0 & 33.8 & 28.7 & 39.3 \\
\hline Trinidad and Tobago & TTO & 34.1 & 3.8 & 33.0 & 28.9 & 40.4 \\
\hline Tunisia & TUN & 34.7 & 3.8 & 35.6 & 26.4 & 40.0 \\
\hline Turkey & TUR & 30.4 & 2.9 & 30.6 & 25.8 & 35.2 \\
\hline Uganda & UGA & 37.0 & 5.8 & 40.3 & 28.0 & 43.7 \\
\hline Ukraine & UKR & 45.5 & 6.0 & 44.5 & 34.9 & 55.7 \\
\hline $\begin{array}{l}\text { United Arab } \\
\text { Emirates }\end{array}$ & ARE & 25.7 & 3.3 & 26.1 & 20.7 & 30.4 \\
\hline United Kingdom & GBR & 10.5 & 1.1 & 10.6 & 8.7 & 12.7 \\
\hline United States & USA & 7.6 & 1.0 & 7.8 & 5.7 & 9.5 \\
\hline Uruguay & URY & 43.0 & 3.9 & 43.4 & 36.3 & 48.4 \\
\hline Venezuela, Rep. Bol. & VEN & 34.3 & 3.0 & 35.4 & 28.7 & 38.3 \\
\hline Vietnam & VNM & 17.8 & 2.6 & 18.7 & 12.5 & 21.3 \\
\hline
\end{tabular}




\begin{tabular}{|l|l|l|l|l|r|r|}
\hline Yemen, Republic of & YEM & 26.2 & 2.9 & 26.6 & 21.5 & 31.1 \\
\hline Zambia & ZMB & 45.4 & 6.4 & 48.6 & 32.5 & 55.7 \\
\hline Zimbabwe & ZWE & 53.9 & 4.7 & 54.0 & 46.0 & 60.1 \\
\hline
\end{tabular}

Table 5. MIMIC Model Estimation Results (night lights instead of GDP): 1991-2017, All Countries

(1)

(2)

(3)

(4)

(5)

(6)

\begin{tabular}{|c|c|c|c|c|c|c|}
\hline \multicolumn{7}{|l|}{ Causes } \\
\hline Trade Openness & $-0.115^{* * *}$ & $-0.114^{* * *}$ & $-0.160 * * *$ & $-0.094 * * *$ & $-0.092 * * *$ & $-0.145^{* * *}$ \\
\hline Unemployment Rate & $0.073^{* * *}$ & $0.077^{* * *}$ & 0.016 & $0.049 *$ & $0.052^{*}$ & $0.076 * * *$ \\
\hline Size of Government & $0.087^{* * *}$ & $0.085^{* * *}$ & 0.025 & & & \\
\hline Fiscal Freedom & & & & $-0.183^{* * *}$ & $-0.195^{* * *}$ & $-0.206^{* * *}$ \\
\hline Rule of Law & $-0.111^{* * *}$ & & & $-0.087 * * *$ & & \\
\hline Control of Corruption & & $-0.067^{* * *}$ & & & $-0.061^{* *}$ & \\
\hline Government Stability & & & -0.021 & & & $0.043^{*}$ \\
\hline \multicolumn{7}{|l|}{ Indicators } \\
\hline Currency & 1 & 1 & 1 & 1 & 1 & 1 \\
\hline Labor Force Participation Rate & $-0.382 * * *$ & $-0.403 * *$ & $-0.672 * * *$ & $-0.388 * * *$ & $-0.374 * * *$ & $-0.335 * * *$ \\
\hline Night Lights & -0.061 & -0.106 & $-1.000 * *$ & -0.107 & -0.127 & $-0.249 * * *$ \\
\hline \multicolumn{7}{|l|}{ Statistical Tests } \\
\hline RMSEA & 0.075 & 0.074 & 0.089 & 0.073 & 0.071 & 0.079 \\
\hline Chi-square (model vs. saturated) & 100.687 & 97.652 & 154.228 & 89.342 & 85.249 & 111.394 \\
\hline Chi-square (baseline vs. saturated) & 229.236 & 201.404 & 386.432 & 246.099 & 230.385 & 352.713 \\
\hline Observations & 2042 & 2036 & 2300 & 1926 & 1925 & 2047 \\
\hline Countries & 147 & 147 & 120 & 145 & 145 & 118 \\
\hline
\end{tabular}

Source: Own calculations.

Note: $* * * \mathrm{p}<0.01, * * \mathrm{p}<0.05, * \mathrm{p}<0.1$

Table 6. Comparing results with countries own statistics (Rank correlation of 85 percent in Sub-Saharan African Countries)

\begin{tabular}{lcc}
\hline Country & $\begin{array}{c}\text { National Account } \\
\text { Stat. }{ }^{\text {1) }}\end{array}$ & MIMIC ${ }^{2)}$ \\
\hline Benin & 55.6 & 49.0 \\
Mali & 55.0 & 40.4 \\
Guinea-Bissau & 53.4 & 38.0 \\
Guinea & 48.1 & 37.0 \\
Senegal & 47.5 & 40.0 \\
Burkina Faso & 43.1 & 32.0 \\
Togo & 40.1 & 28.0 \\
Cote d'Ivore & 34.0 & 35.0 \\
\hline
\end{tabular}

1) Mostly descrepancy method.

2) Our results.

Source: own computations and Medina et.al 2017 for the National Account Stat. 
Table 7: Interactions between the shadow and the official economy

\begin{tabular}{|c|c|c|}
\hline $\begin{array}{l}\text { The shadow } \\
\text { economy influences }\end{array}$ & Through & $\begin{array}{l}\text { Effects on official economy and } \\
\text { overall economic performance }\end{array}$ \\
\hline Tax system $\downarrow$ & Tax evasion & $\begin{array}{l}\text { Redistribution policies to finance } \\
\text { qualitative and quantitative } \\
\text { improvements of public goods are } \\
\text { impaired, thus economic growth may } \\
\text { be negatively affected (Schneider } \\
(2005,2010))\end{array}$ \\
\hline & $\begin{array}{l}\text { Additional } \\
\text { tax revenues }\end{array}$ & $\begin{array}{l}\text { If the shadow economy activity is } \\
\text { complementary to the official } \\
\text { economy, extra income is generated via } \\
\text { the shadow economy which is then (at } \\
\text { least partly) spent in the official } \\
\text { economy for goods and services } \\
\text { (Schneider }(2005,2010))\end{array}$ \\
\hline Allocations & $\begin{array}{l}\text { Stronger competition } \\
\text { and stimulation of } \\
\text { markets }\end{array}$ & $\begin{array}{l}\text { More efficient use of scarce resources } \\
\text { (Schneider }(2005,2010) \text { ) } \\
\text { Incentives for firms and individuals, } \\
\text { stimulation of creativity and innovation } \\
\text { Enlargement of market supply through } \\
\text { additional good and services } \\
\text { Cost advantages of producers acting } \\
\text { from the shadow economy may lead to } \\
\text { ruinous competition } \\
\text { Problems in information flows for } \\
\text { producers and consumers due to } \\
\text { reduction in transparency and lack of } \\
\text { structure in unofficial sector }\end{array}$ \\
\hline Policy decisions & $\begin{array}{l}\text { Bias in officially } \\
\text { published data }\end{array}$ & $\begin{array}{l}\text { Stabilizing, re-distributional and fiscal } \\
\text { policies may fail desired effects }\end{array}$ \\
\hline
\end{tabular}

Source: Schneider and Hametner (2014, p. 298).

1) For a more detailed discussion on outcomes of economic policy based on biased data compare McGee and Feige (1989), Fleming, Roman, and Farrell (2000), Schneider (2005, 2010), Schneider and Enste (2002). 
Table 8: Interaction between Official and Unofficial Sectors

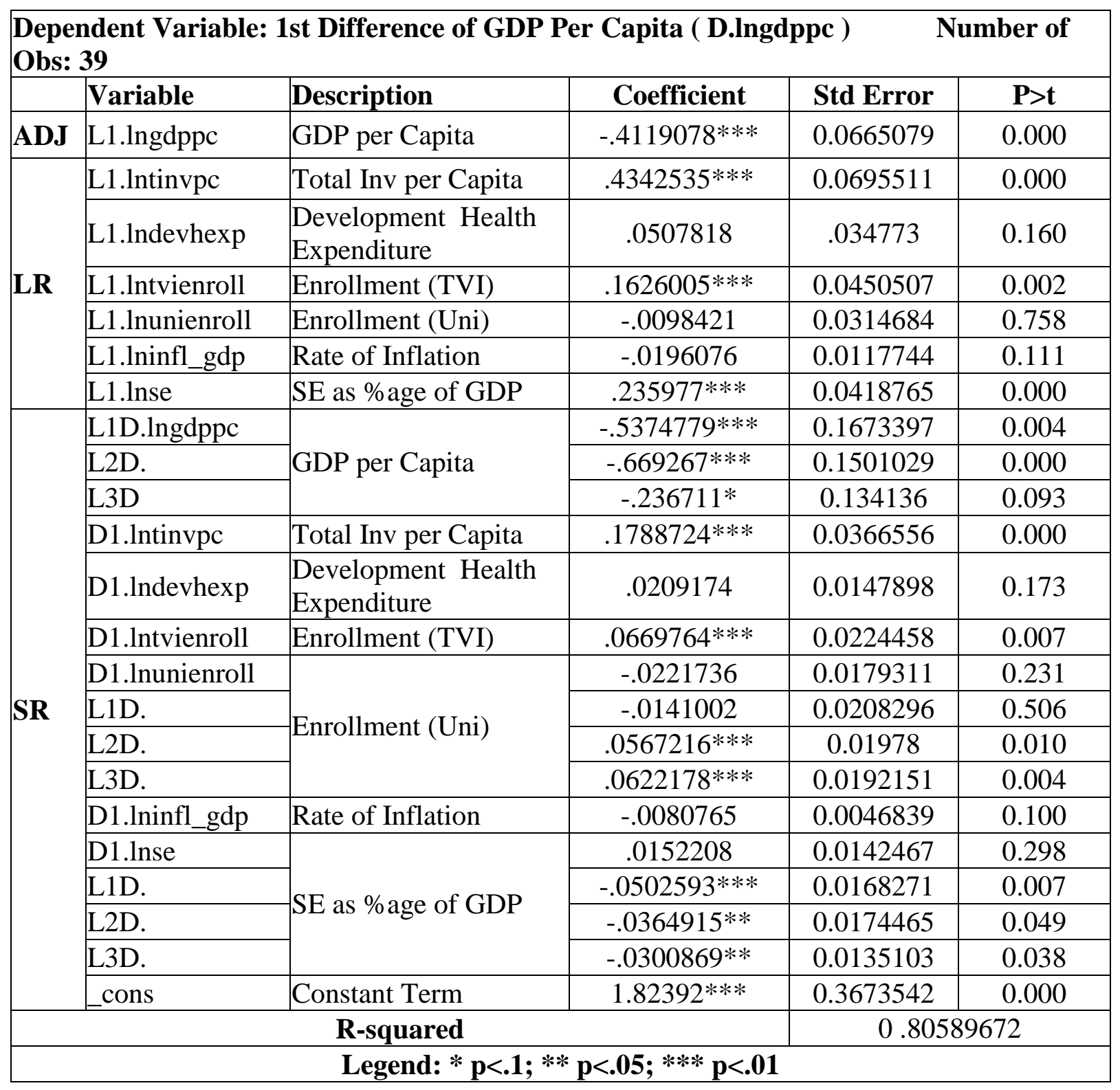

Source: Mughal and Schneider (2019). 
Table 9 : Bounds Test for Cointegration

\begin{tabular}{|c|c|c|c|}
\hline F-statistics calculated & $\begin{array}{c}\text { Lower Bound } \\
\text { Critical Value at } \\
\mathbf{9 5 \%}\end{array}$ & $\begin{array}{c}\text { Upper Bound } \\
\text { Critical Value at } \\
\mathbf{9 5 \%}\end{array}$ & Decision \\
\hline 7.584 & 2.45 & 3.61 & Co-integration exists \\
\hline
\end{tabular}

Source: Moughal and Schneider (2018).

\section{Table 10: Diagnostic Tests for Interaction Model}

\begin{tabular}{|l|ll|}
\hline $\begin{array}{l}\text { Breusch-Godfrey LM test for autocorrelation } \\
\text { HO: } \text { no serial correlation }\end{array}$ & chi2 $=0.121$ & Prob > chi2 $=0.7285$ \\
\hline $\begin{array}{l}\text { Breusch-Pagan/Cook-Weisberg test for heteroskedasticity } \\
\text { Ho: } \text { Constant variance }\end{array}$ & chi2 $=2.91$ & Prob > chi2 $=0.0879$ \\
\hline \multicolumn{2}{|c|}{ Cameron \& Trivedi's decomposition of IM-test } \\
\hline Heteroskedasticity & chi2 $=40.00$ & Prob > chi2 $=0.4256$ \\
\hline Skewness & chi2 $=7.13$ & Prob > chi2 $=0.7134$ \\
\hline Kurtosis & chi2 $=2.29$ & Prob > chi2 $=0.1299$ \\
\hline Total & chi2 $=49.42$ & Prob $>$ chi2 $=0.4965$ \\
\hline
\end{tabular}

Source: Moughal and Schneider (2018).

\section{Table 11: Influence of Shadow Economy of Official Sector}

\begin{tabular}{|c|c|c|c|}
\hline year & $\begin{array}{c}\text { Official GDP per Capita } \\
\text { (Pak Rupees) }\end{array}$ & $\begin{array}{c}\text { GDP per capita with no Shadow } \\
\text { Economy (LR Effect Only) }\end{array}$ & $\begin{array}{c}\text { GDP per capita with no Shadow } \\
\text { Economy (LR and SR Effect) }\end{array}$ \\
\hline $\mathbf{1 9 8 0}$ & 24917.80 & 21233.24 & 21540.01 \\
\hline $\mathbf{1 9 8 5}$ & 29562.80 & 25759.60 & 32501.56 \\
\hline $\mathbf{1 9 9 0}$ & 33320.60 & 31748.93 & 30414.39 \\
\hline $\mathbf{1 9 9 5}$ & 38512.40 & 29920.80 & 37594.46 \\
\hline $\mathbf{2 0 0 0}$ & 41114.90 & 37271.55 & 45961.90 \\
\hline $\mathbf{2 0 0 5}$ & 47803.90 & 45611.52 & 41481.42 \\
\hline $\mathbf{2 0 1 0}$ & 51251.30 & 40917.82 & 48879.25 \\
\hline $\mathbf{2 0 1 5}$ & 56061.20 & 48208.04 & \\
\hline
\end{tabular}

Source: Moughal and Schneider (2018) 
Figure 1. Size of the Shadow Economy in \% of GDP of the 15 countries with the highest and the lowest shadow economy - Part (I) highest; average over 1991 to 2017

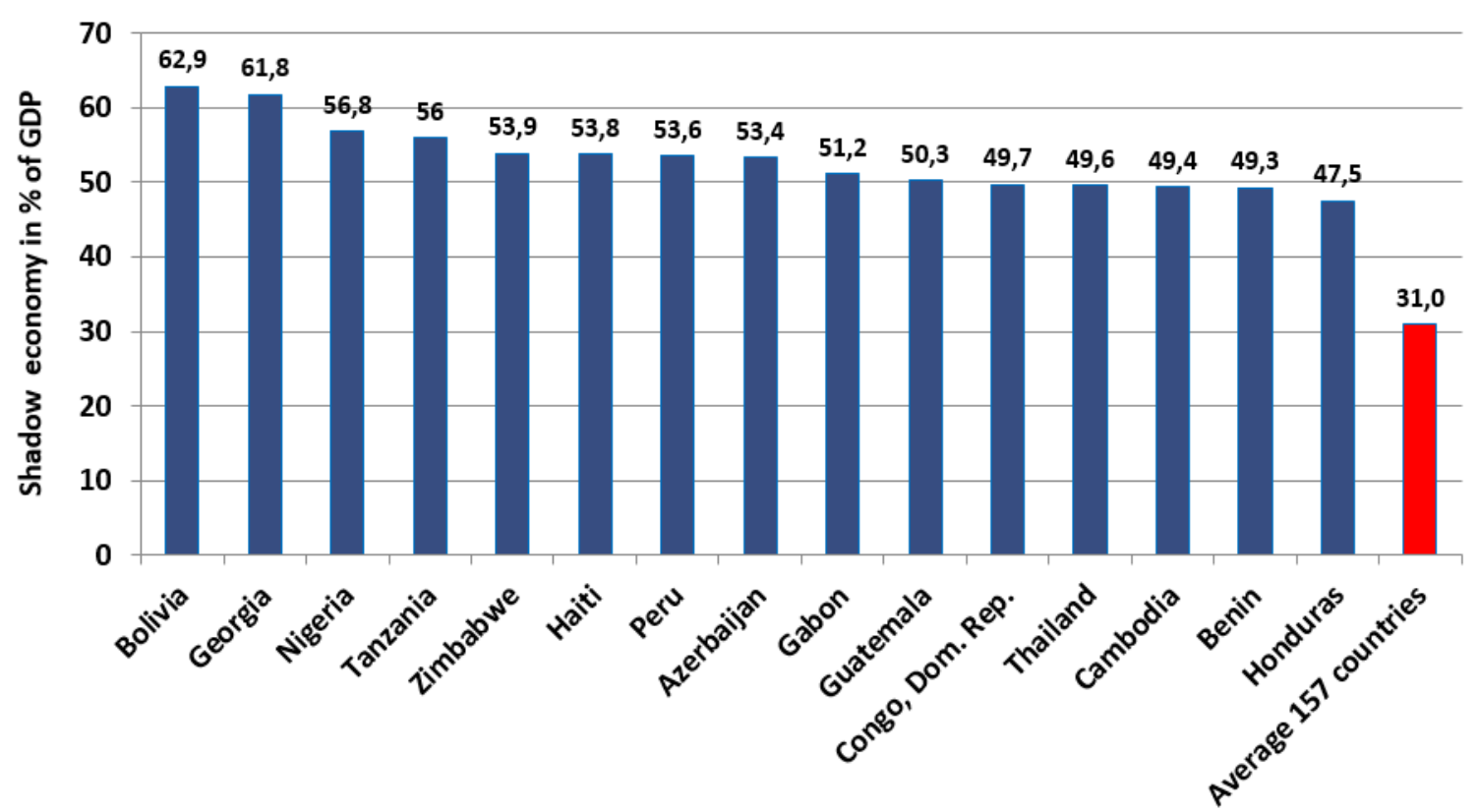

Figure 2. Size of the Shadow Economy in \% of GDP of the 15 countries with the highest and the lowest shadow economy - Part (II) lowest, average over 1991 to 2017

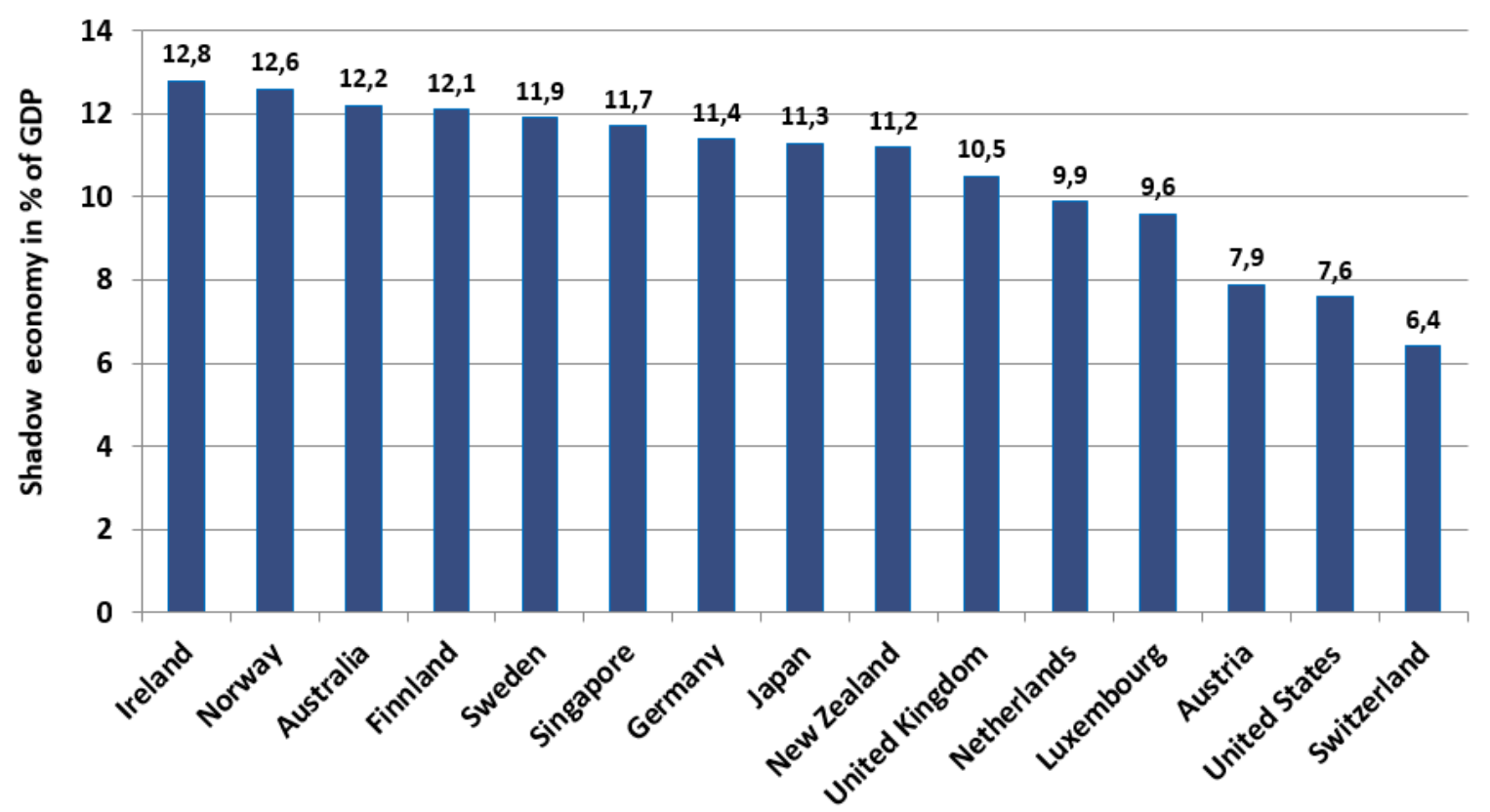


Figure 3. Shadow Economy by Region (average, percent of GDP)

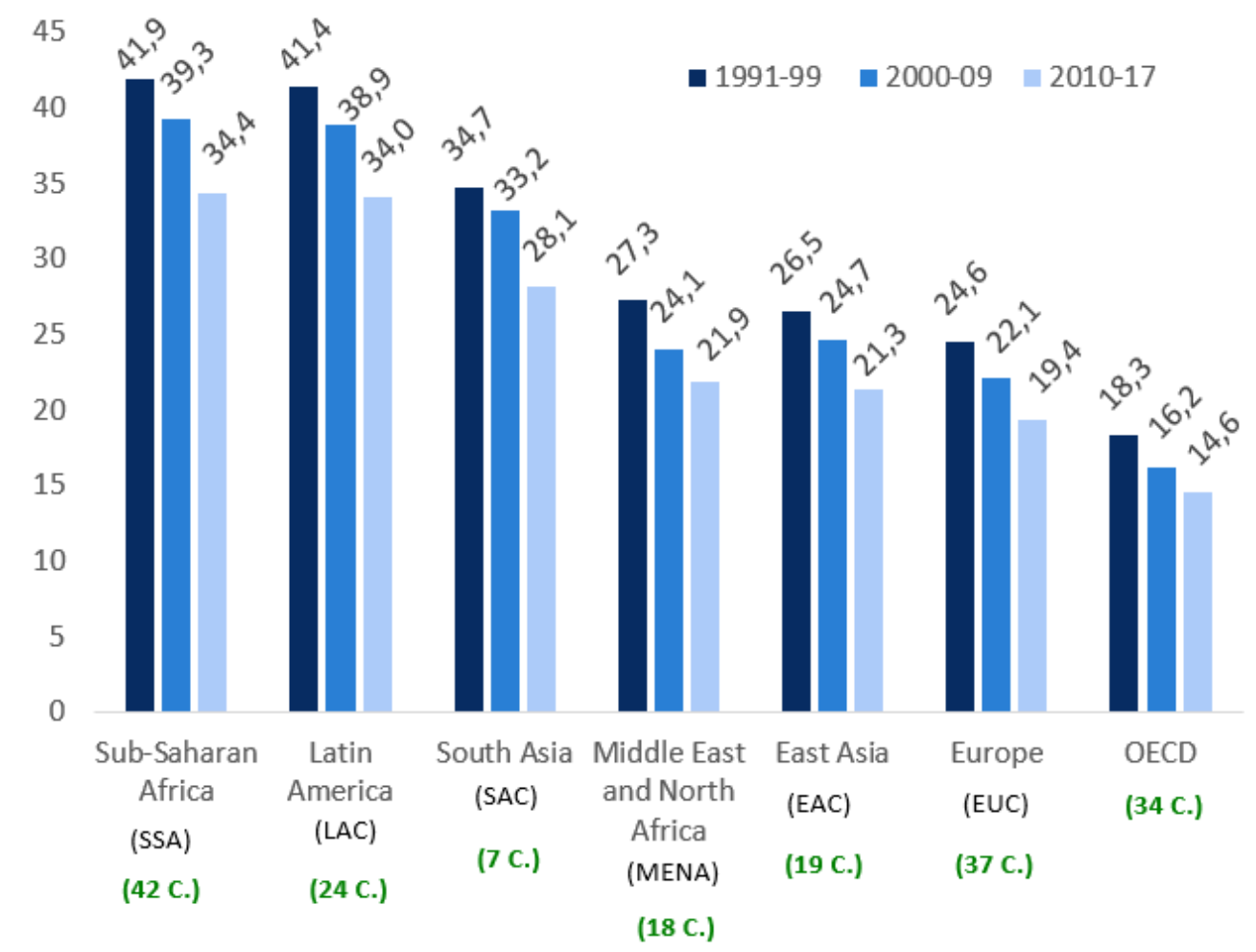

Figure 4. Shadow Economy by Income Level (average, percent of GDP)

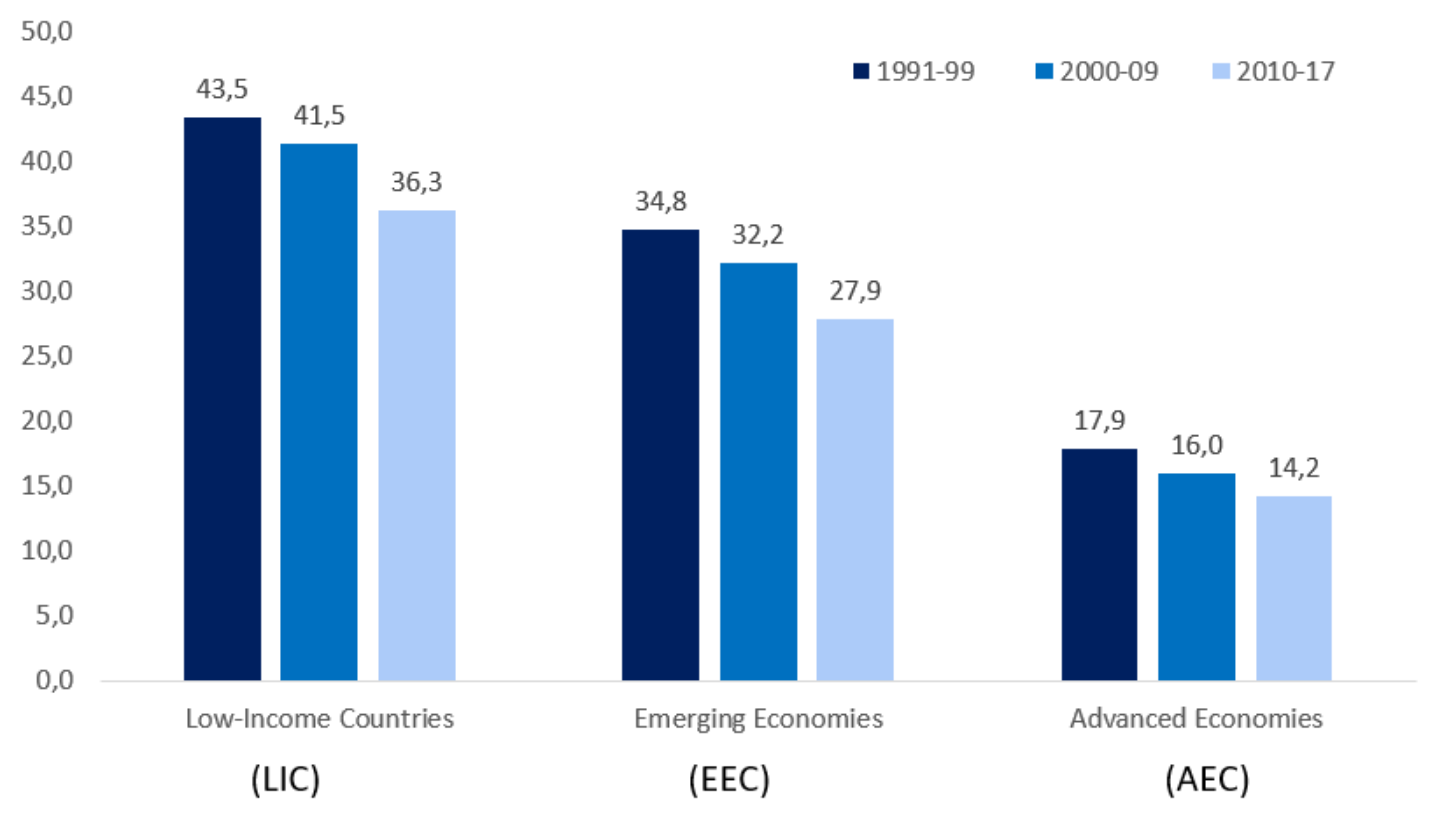


Figure 5. Influence of Shadow Economy on Official Sector of Pakistan

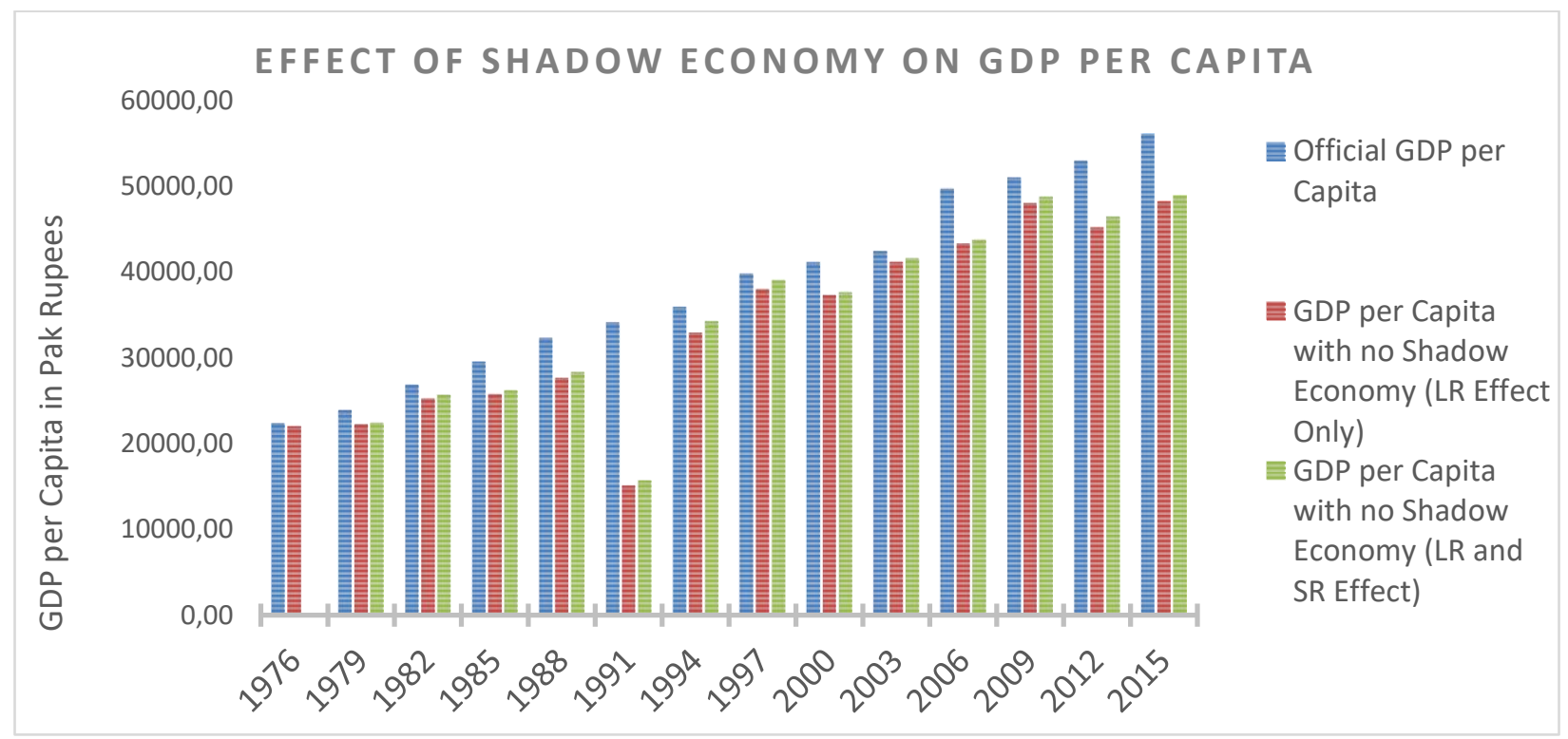

Source: Mughal and Schneider (2018) 


\section{APPENDIX A}

Table A.1: Size and development of the shadow economy, 1991 to 2017 - Part I (1991-2004)

\begin{tabular}{|c|c|c|c|c|c|c|c|c|c|c|c|c|c|c|c|}
\hline Country & ISO & 1991 & 1992 & 1993 & 1994 & 1995 & 1996 & 1997 & 1998 & 1999 & 2000 & 2001 & 2002 & 2003 & 2004 \\
\hline Albania & ALB & 42.1 & 38.2 & 36.9 & 37.8 & 37.5 & 35.9 & 36.5 & 37.1 & 35.8 & 35.3 & 34.3 & 34.5 & 33.6 & 32.4 \\
\hline Algeria & DZA & 34.9 & 35.7 & 36.6 & 37.1 & 36.1 & 36.3 & 36.0 & 37.9 & 36.3 & 34.2 & 34.4 & 33.8 & 32.7 & 30.9 \\
\hline Angola & AGO & 50.7 & 51.5 & 50.1 & 51.5 & 52.0 & 48.6 & 51.9 & 50.2 & 52.7 & 48.8 & 46.4 & 47.3 & 47.2 & 45.5 \\
\hline Argentina & ARG & 25.6 & 24.6 & 26.9 & 26.3 & 26.3 & 24.9 & 25.0 & 24.4 & 25.9 & 25.4 & 26.4 & 28.5 & 27.8 & 27.0 \\
\hline Armenia & ARM & 48.1 & 48.7 & 47.4 & 43.5 & 45.2 & 46.2 & 45.8 & 45.6 & 46.6 & 46.6 & 45.8 & 44.4 & 43.2 & 43.6 \\
\hline Australia & AUS & 14.4 & 15.2 & 14.9 & 14.2 & 13.6 & 13.6 & 13.0 & 12.9 & 13.4 & 13.1 & 12.8 & 12.8 & 12.4 & 12.2 \\
\hline Austria & AUT & 8.6 & 8.6 & 9.1 & 9.0 & 8.7 & 8.8 & 8.9 & 8.8 & 9.0 & 8.8 & 8.6 & 8.4 & 8.0 & 7.6 \\
\hline Azerbaijan & $\mathbf{A Z E}$ & 59.3 & 55.8 & 62.1 & 64.9 & 58.3 & 59.8 & 58.4 & 60.7 & 60.4 & 60.6 & 58.7 & 57.0 & 55.6 & 54.6 \\
\hline Bahamas, The & BHS & 33.7 & 33.9 & 33.3 & 34.2 & 33.5 & 33.1 & 28.9 & 27.8 & 27.1 & 26.2 & 27.0 & 26.2 & 26.4 & 26.3 \\
\hline Bahrain & BHR & 20.0 & 20.1 & 20.0 & 19.8 & 19.8 & 20.0 & 19.5 & 20.3 & 19.9 & 18.4 & 18.9 & 18.6 & 18.1 & 16.9 \\
\hline Bangladesh & BGD & 35.1 & 35.9 & 36.9 & 36.7 & 35.2 & 35.5 & 35.5 & 36.2 & 35.6 & 35.6 & 34.7 & 35.7 & 36.3 & 36.1 \\
\hline Belarus & BLR & 52.9 & 46.5 & 46.6 & 47.7 & 50.8 & 49.9 & 49.4 & 48.2 & 49.6 & 48.1 & 49.8 & 50.0 & 49.1 & 47.4 \\
\hline Belgium & BEL & 20.7 & 20.4 & 20.9 & 20.4 & 19.6 & 19.9 & 19.9 & 20.3 & 19.9 & 19.9 & 20.1 & 20.1 & 19.4 & 18.3 \\
\hline Belize & BLZ & 56.9 & 51.6 & 53.2 & 53.3 & 51.4 & 49.9 & 51.2 & 49.9 & 47.9 & 43.8 & 45.1 & 46.0 & 45.4 & 44.7 \\
\hline Benin & BEN & 56.2 & 56.2 & 53.9 & 55.5 & 52.5 & 51.0 & 52.4 & 50.0 & 49.5 & 50.2 & 51.1 & 50.0 & 50.6 & 50.0 \\
\hline Bhutan & BTN & 28.8 & 28.5 & 28.3 & 27.8 & 26.1 & 29.6 & 29.3 & 28.5 & 27.8 & 29.4 & 29.1 & 29.0 & 28.1 & 27.0 \\
\hline Bolivia & BOL & 66.2 & 67.0 & 68.0 & 68.0 & 67.4 & 64.9 & 67.0 & 65.1 & 69.0 & 67.1 & 70.5 & 69.3 & 69.9 & 69.1 \\
\hline Bosnia and Herzegovina & BIH & 30.4 & 30.8 & 31.1 & 37.4 & 39.5 & 35.8 & 34.4 & 32.5 & 32.8 & 34.1 & 33.6 & 37.9 & 35.7 & 33.5 \\
\hline Botswana & BWA & 33.2 & 34.4 & 35.2 & 35.3 & 34.8 & 34.6 & 33.3 & 34.5 & 33.5 & 33.4 & 33.4 & 33.5 & 30.8 & 29.1 \\
\hline Brazil & BRA & 40.0 & 40.4 & 40.5 & 38.4 & 41.5 & 40.6 & 39.9 & 40.7 & 41.2 & 39.8 & 39.9 & 40.5 & 39.9 & 38.5 \\
\hline Brunei Darussalam & BRN & 30.7 & 30.7 & 31.6 & 32.6 & 30.7 & 29.2 & 30.1 & 32.9 & 32.7 & 31.1 & 32.0 & 31.3 & 30.2 & 29.6 \\
\hline Bulgaria & BGR & 34.8 & 34.9 & 34.6 & 33.6 & 32.6 & 32.8 & 30.7 & 34.8 & 34.5 & 35.3 & 34.7 & 34.0 & 34.1 & 32.1 \\
\hline Burkina Faso & BFA & 39.2 & 41.9 & 41.6 & 43.6 & 42.2 & 43.1 & 42.1 & 41.3 & 39.2 & 41.4 & 43.3 & 41.4 & 39.1 & 38.1 \\
\hline Burundi & BDI & 32.8 & 36.6 & 38.4 & 37.3 & 37.3 & 41.5 & 38.6 & 39.3 & 40.4 & 39.5 & 39.5 & 39.7 & 40.7 & 40.5 \\
\hline Cabo Verde & CPV & 39.0 & 40.1 & 41.3 & 40.2 & 40.2 & 36.7 & 39.0 & 36.8 & 36.9 & 36.1 & 35.1 & 35.7 & 35.9 & 34.9 \\
\hline Cambodia & KHM & 49.6 & 51.5 & 54.4 & 57.9 & 54.2 & 55.5 & 54.4 & 52.7 & 51.6 & 50.1 & 49.7 & 54.1 & 53.2 & 49.5 \\
\hline Cameroon & CMR & 34.3 & 34.2 & 35.0 & 33.5 & 33.7 & 34.5 & 32.3 & 32.2 & 33.7 & 32.8 & 33.4 & 33.0 & 32.1 & 31.1 \\
\hline
\end{tabular}

\section{$\underline{\text { Appendix A }}$}


Table A.1: Size and development of the shadow economy, 1991 to 2017 - Part I (1991-2004) (cont.)

\begin{tabular}{|c|c|c|c|c|c|c|c|c|c|c|c|c|c|c|c|}
\hline Country & ISO & 1991 & 1992 & 1993 & 1994 & 1995 & 1996 & 1997 & 1998 & 1999 & 2000 & 2001 & 2002 & 2003 & 2004 \\
\hline Canada & CAN & 16.5 & 16.6 & 16.3 & 15.6 & 15.0 & 14.9 & 14.1 & 14.0 & 13.6 & 13.4 & 13.6 & 14.0 & 13.7 & 13.1 \\
\hline Central African Republic & CAF & 37.3 & 37.6 & 38.9 & 42.0 & 39.2 & 39.9 & 39.3 & 39.4 & 42.7 & 42.6 & 43.0 & 41.9 & 41.1 & 41.0 \\
\hline Chad & TCD & 46.4 & 46.6 & 47.4 & 47.3 & 46.6 & 46.2 & 46.8 & 45.7 & 47.0 & 46.2 & 46.3 & 41.7 & 43.9 & 40.8 \\
\hline Chile & CHL & 18.7 & 18.5 & 18.8 & 18.6 & 18.0 & 18.9 & 18.4 & 19.0 & 19.3 & 18.9 & 19.0 & 18.9 & 18.5 & 17.2 \\
\hline China & CHN & 15.7 & 15.8 & 15.5 & 15.4 & 14.9 & 14.9 & 15.0 & 15.5 & 16.4 & 16.5 & 16.0 & 15.6 & 14.9 & 14.1 \\
\hline Colombia & COL & 37.1 & 37.4 & 36.4 & 36.1 & 36.1 & 38.0 & 38.1 & 39.0 & 40.1 & 39.1 & 37.9 & 38.5 & 36.8 & 36.3 \\
\hline Comoros & COM & 34.0 & 33.4 & 34.0 & 37.9 & 36.1 & 36.3 & 37.5 & 38.1 & 37.6 & 39.6 & 38.1 & 37.1 & 34.5 & 33.4 \\
\hline Congo, Dem. Rep. & COD & 48.4 & 50.0 & 48.4 & 54.7 & 54.5 & 55.1 & 56.3 & 56.4 & 56.5 & 48.0 & 55.4 & 54.9 & 53.2 & 53.1 \\
\hline Congo, Rep. & COG & 54.7 & 54.7 & 56.4 & 52.3 & 50.0 & 48.6 & 51.2 & 54.2 & 49.6 & 48.2 & 48.9 & 49.8 & 47.8 & 46.5 \\
\hline Costa Rica & CRI & 26.0 & 25.0 & 24.9 & 25.1 & 24.6 & 24.4 & 23.9 & 22.8 & 24.1 & 23.9 & 24.7 & 24.3 & 23.9 & 23.8 \\
\hline Cote d'Ivoire & CIV & 43.9 & 44.1 & 43.7 & 42.7 & 39.5 & 38.5 & 42.1 & 40.6 & 41.5 & 43.2 & 42.8 & 41.6 & 41.6 & 40.3 \\
\hline Croatia & HRV & 27.6 & 28.7 & 29.6 & 31.4 & 34.4 & 33.8 & 31.9 & 33.3 & 33.4 & 32.0 & 30.4 & 29.8 & 27.9 & 26.6 \\
\hline Cyprus & CYP & 34.5 & 34.0 & 33.6 & 33.0 & 26.8 & 27.5 & 28.5 & 29.4 & 29.4 & 28.7 & 29.4 & 29.9 & 30.0 & 27.8 \\
\hline Czech Republic & CZE & 18.6 & 17.7 & 17.8 & 17.9 & 16.9 & 16.4 & 16.8 & 16.1 & 16.7 & 16.8 & 16.2 & 17.0 & 17.2 & 15.9 \\
\hline Denmark & DNK & 15.3 & 15.0 & 15.8 & 15.1 & 14.3 & 14.6 & 14.3 & 14.6 & 14.6 & 14.6 & 14.5 & 14.6 & 13.9 & 13.2 \\
\hline Dominican Republic & DOM & 34.7 & 32.4 & 32.5 & 32.4 & 32.3 & 31.7 & 32.5 & 31.7 & 32.4 & 32.1 & 32.9 & 33.1 & 32.4 & 32.2 \\
\hline Ecuador & ECU & 37.5 & 36.5 & 37.0 & 36.6 & 36.4 & 35.3 & 36.1 & 35.5 & 37.5 & 34.4 & 35.1 & 34.6 & 34.9 & 34.1 \\
\hline Egypt, Arab Rep. & EGY & 36.2 & 35.2 & 35.1 & 35.3 & 35.3 & 34.4 & 36.1 & 35.6 & 36.6 & 35.1 & 35.9 & 37.6 & 37.6 & 37.0 \\
\hline El Salvador & SLV & 51.3 & 50.5 & 48.9 & 47.9 & 46.8 & 48.4 & 46.2 & 46.7 & 46.8 & 46.3 & 46.4 & 45.7 & 44.6 & 43.6 \\
\hline Equatorial Guinea & GNQ & 35.1 & 35.3 & 36.2 & 35.0 & 35.4 & 34.2 & 34.3 & 35.8 & 33.8 & 32.8 & 32.6 & 32.9 & 32.1 & 31.4 \\
\hline Estonia & EST & 22.5 & 23.7 & 28.2 & 28.4 & 29.1 & 29.0 & 26.8 & 26.8 & 27.3 & 27.7 & 26.8 & 26.7 & 26.0 & 24.7 \\
\hline Ethiopia & ETH & 35.4 & 34.8 & 35.6 & 36.4 & 36.2 & 36.5 & 36.0 & 37.0 & 39.1 & 40.3 & 38.7 & 39.8 & 40.3 & 38.5 \\
\hline Fiji & FJI & 34.7 & 34.9 & 35.2 & 32.1 & 31.2 & 30.0 & 31.7 & 33.1 & 31.2 & 33.6 & 33.9 & 32.6 & 30.6 & 28.0 \\
\hline Finland & FIN & 14.4 & 14.7 & 14.7 & 14.0 & 13.2 & 13.5 & 13.1 & 12.7 & 12.7 & 12.5 & 12.6 & 12.7 & 12.1 & 11.5 \\
\hline France & FRA & 14.1 & 14.2 & 15.3 & 14.9 & 14.2 & 14.3 & 14.6 & 14.0 & 14.0 & 13.8 & 13.7 & 14.5 & 13.6 & 12.6 \\
\hline Gabon & GAB & 54.1 & 55.2 & 56.8 & 52.3 & 51.8 & 50.7 & 50.3 & 54.8 & 52.6 & 48.0 & 57.8 & 56.1 & 56.1 & 54.1 \\
\hline Gambia, The & GMB & 43.9 & 44.6 & 44.7 & 43.9 & 43.1 & 41.6 & 44.3 & 41.7 & 44.2 & 45.1 & 48.8 & 48.9 & 48.2 & 45.8 \\
\hline
\end{tabular}

\section{$\underline{\text { Appendix A }}$}


40

Table A.1: Size and development of the shadow economy, 1991 to 2017 - Part I (1991-2004) (cont.)

\begin{tabular}{|c|c|c|c|c|c|c|c|c|c|c|c|c|c|c|c|}
\hline Country & ISO & 1991 & 1992 & 1993 & 1994 & 1995 & 1996 & 1997 & 1998 & 1999 & 2000 & 2001 & 2002 & 2003 & 2004 \\
\hline Georgia & GEO & 64.4 & 64.2 & 62.6 & 61.4 & 67.8 & 68.8 & 67.2 & 69.1 & 68.1 & 67.3 & 66.7 & 66.9 & 65.5 & 65.5 \\
\hline Germany & DEU & 13.0 & 13.1 & 13.3 & 13.1 & 12.5 & 13.0 & 12.9 & 12.7 & 12.8 & 12.9 & 12.7 & 12.8 & 12.2 & 11.2 \\
\hline Ghana & GHA & 44.8 & 46.8 & 48.3 & 47.7 & 46.4 & 46.5 & 45.1 & 45.1 & 44.1 & 41.9 & 42.5 & 42.8 & 43.6 & 44.2 \\
\hline Greece & GRC & 27.6 & 26.9 & 27.7 & 27.2 & 27.2 & 26.3 & 26.9 & 26.4 & 26.6 & 26.1 & 26.6 & 26.4 & 24.7 & 23.2 \\
\hline Guatemala & GTM & 56.2 & 56.0 & 55.8 & 54.6 & 53.6 & 54.4 & 52.3 & 52.6 & 53.1 & 51.5 & 53.8 & 52.5 & 53.1 & 50.5 \\
\hline Guinea & GIN & 38.1 & 37.6 & 37.6 & 37.8 & 37.2 & 37.5 & 37.6 & 37.5 & 38.5 & 39.7 & 40.0 & 38.9 & 38.5 & 38.3 \\
\hline Guinea-Bissau & GNB & 38.2 & 37.4 & 38.2 & 37.2 & 37.2 & 38.7 & 35.6 & 40.2 & 37.3 & 39.6 & 38.8 & 38.7 & 38.5 & 36.8 \\
\hline Guyana & GUY & 32.1 & 31.6 & 31.5 & 31.8 & 31.5 & 30.9 & 31.8 & 31.7 & 32.5 & 33.6 & 33.8 & 34.0 & 34.8 & 34.5 \\
\hline Haiti & HTI & 55.5 & 59.9 & 54.7 & 62.7 & 56.1 & 61.4 & 57.8 & 56.2 & 53.9 & 55.4 & 57.7 & 60.0 & 58.0 & 54.1 \\
\hline Honduras & HND & 52.7 & 52.8 & 51.8 & 50.6 & 49.4 & 48.8 & 47.8 & 47.9 & 49.3 & 49.6 & 50.4 & 50.0 & 49.4 & 47.5 \\
\hline Hong Kong SAR, China & HKG & 17.1 & 16.8 & 16.3 & 15.9 & 15.9 & 16.2 & 15.3 & 16.4 & 16.6 & 16.6 & 16.7 & 17.1 & 17.0 & 16.3 \\
\hline Hungary & HUN & 29.1 & 29.2 & 30.1 & 28.9 & 27.2 & 26.3 & 26.2 & 25.5 & 25.7 & 25.1 & 25.1 & 24.5 & 24.2 & 22.6 \\
\hline Iceland & ISL & 14.3 & 14.6 & 15.0 & 14.8 & 14.7 & 14.6 & 14.3 & 14.2 & 14.3 & 14.3 & 14.7 & 14.8 & 14.3 & 13.1 \\
\hline India & IND & 27.3 & 27.0 & 27.1 & 26.1 & 26.1 & 25.1 & 26.5 & 26.9 & 27.8 & 26.7 & 27.2 & 26.5 & 25.2 & 24.0 \\
\hline Indonesia & IDN & 26.8 & 26.9 & 26.5 & 25.6 & 24.9 & 24.1 & 24.0 & 22.3 & 24.2 & 23.7 & 24.0 & 25.1 & 25.6 & 25.1 \\
\hline Iran, Islamic Rep. & IRN & 14.3 & 14.2 & 20.2 & 20.4 & 20.5 & 19.5 & 19.5 & 20.0 & 19.5 & 18.9 & 19.4 & 18.3 & 17.6 & 17.1 \\
\hline Ireland & IRL & 15.7 & 15.6 & 15.6 & 15.4 & 14.8 & 14.7 & 14.2 & 13.8 & 13.4 & 13.4 & 13.2 & 13.2 & 13.0 & 12.5 \\
\hline Israel & ISR & 25.9 & 25.1 & 24.8 & 24.3 & 24.2 & 23.4 & 24.0 & 23.8 & 23.3 & 21.9 & 23.2 & 23.6 & 23.5 & 22.1 \\
\hline Italy & ITA & 25.8 & 25.1 & 26.2 & 25.2 & 23.1 & 21.9 & 23.1 & 22.3 & 23.0 & 22.7 & 23.7 & 23.0 & 22.0 & 21.1 \\
\hline Jamaica & JAM & 38.8 & 36.7 & 37.9 & 35.1 & 34.5 & 35.7 & 36.1 & 36.4 & 36.2 & 36.4 & 36.4 & 36.2 & 36.5 & 34.2 \\
\hline Japan & JPN & 12.7 & 12.3 & 11.5 & 10.8 & 9.9 & 11.0 & 11.7 & 12.5 & 11.7 & 11.2 & 12.3 & 13.0 & 12.4 & 11.5 \\
\hline Jordan & JOR & 19.9 & 19.2 & 19.3 & 19.5 & 19.4 & 19.5 & 19.8 & 19.7 & 19.8 & 19.4 & 19.3 & 19.5 & 18.8 & 17.7 \\
\hline Kazakhstan & KAZ & 45.6 & 45.3 & 45.0 & 42.5 & 45.1 & 45.9 & 44.6 & 44.0 & 43.6 & 43.2 & 44.3 & 43.1 & 42.4 & 41.6 \\
\hline Kenya & KEN & 35.8 & 35.3 & 33.3 & 33.6 & 32.9 & 34.1 & 34.2 & 35.6 & 35.2 & 34.3 & 34.8 & 35.7 & 36.3 & 35.3 \\
\hline Korea, Rep. & KOR & 29.3 & 29.3 & 29.0 & 28.1 & 27.1 & 27.5 & 27.0 & 29.4 & 28.2 & 27.5 & 28.1 & 27.6 & 27.6 & 26.4 \\
\hline Kuwait & KWT & 22.5 & 20.3 & 19.5 & 19.2 & 20.7 & 20.0 & 20.4 & 20.7 & 21.1 & 20.1 & 20.7 & 20.6 & 19.7 & 18.8 \\
\hline Kyrgyz Republic & KGZ & 40.6 & 40.4 & 40.7 & 40.5 & 41.1 & 38.7 & 38.9 & 38.4 & 40.9 & 41.2 & 40.1 & 39.7 & 37.7 & 37.9 \\
\hline
\end{tabular}


Appendix A

Table A.1: Size and development of the shadow economy, 1991 to 2017 - Part I (1991-2004) (cont.)

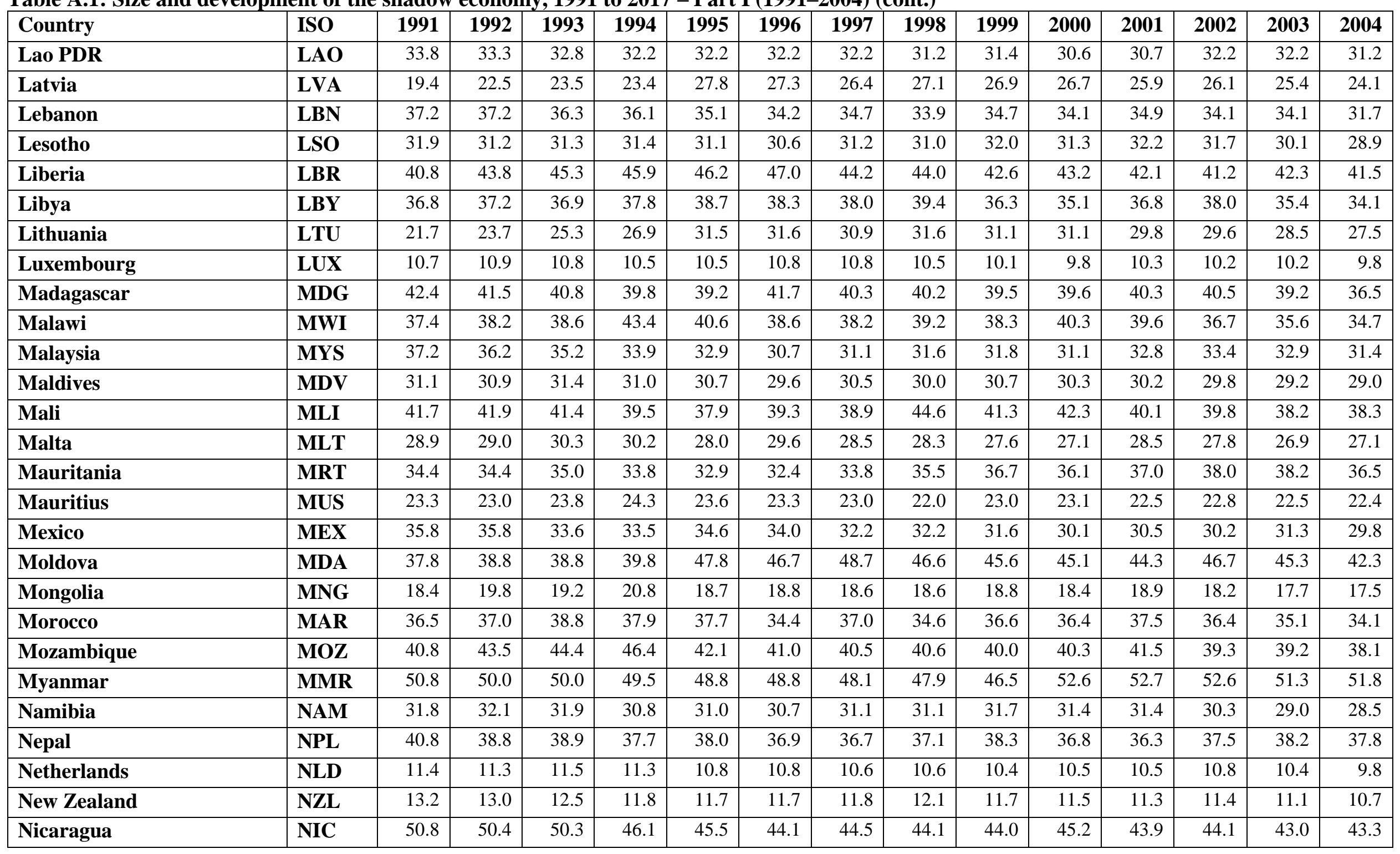




\section{$\underline{\text { Appendix A }}$}

Table A.1: Size and development of the shadow economy, 1991 to 2017 - Part I (1991-2004) (cont.)

\begin{tabular}{|c|c|c|c|c|c|c|c|c|c|c|c|c|c|c|c|}
\hline Country & ISO & 1991 & 1992 & 1993 & 1994 & 1995 & 1996 & 1997 & 1998 & 1999 & 2000 & 2001 & 2002 & 2003 & 2004 \\
\hline Niger & NER & 40.1 & 42.5 & 43.7 & 43.3 & 40.9 & 39.5 & 41.5 & 40.6 & 43.4 & 41.9 & 40.5 & 40.2 & 41.8 & 41.8 \\
\hline Nigeria & NGA & 60.2 & 60.7 & 62.9 & 64.0 & 60.4 & 59.9 & 57.8 & 60.4 & 60.8 & 57.9 & 58.2 & 59.6 & 57.6 & 61.4 \\
\hline Norway & NOR & 14.1 & 14.7 & 14.8 & 14.5 & 14.1 & 13.5 & 13.0 & 13.6 & 13.8 & 12.7 & 12.9 & 14.2 & 14.0 & 12.6 \\
\hline Oman & OMN & 20.7 & 20.4 & 20.7 & 20.7 & 20.6 & 19.5 & 19.7 & 20.0 & 19.9 & 18.9 & 19.5 & 19.6 & 19.0 & 18.3 \\
\hline Pakistan & PAK & 39.3 & 37.6 & 37.5 & 37.7 & 36.7 & 35.7 & 36.8 & 36.6 & 37.0 & 36.8 & 35.3 & 35.5 & 34.3 & 34.5 \\
\hline Papua New Guinea & PNG & 39.3 & 39.0 & 39.1 & 36.4 & 36.0 & 35.6 & 37.0 & 36.4 & 36.4 & 36.1 & 36.4 & 36.4 & 36.6 & 34.8 \\
\hline Paraguay & PRY & 35.6 & 36.8 & 36.1 & 35.5 & 35.4 & 36.2 & 37.6 & 38.0 & 39.0 & 39.8 & 39.2 & 39.0 & 38.1 & 37.0 \\
\hline Peru & PER & 57.6 & 57.7 & 57.9 & 57.8 & 57.8 & 58.1 & 57.4 & 59.0 & 60.0 & 59.9 & 59.9 & 58.2 & 58.2 & 56.1 \\
\hline Philippines & PHL & 45.8 & 44.8 & 44.9 & 45.0 & 44.7 & 42.8 & 45.0 & 44.9 & 44.8 & 43.3 & 43.7 & 42.5 & 42.3 & 41.0 \\
\hline Poland & POL & 29.7 & 29.9 & 29.8 & 29.2 & 27.7 & 27.0 & 26.9 & 25.9 & 26.6 & 26.2 & 26.4 & 26.1 & 25.9 & 25.3 \\
\hline Portugal & PRT & 22.0 & 21.5 & 22.5 & 22.1 & 21.3 & 20.8 & 21.3 & 20.7 & 21.1 & 21.4 & 21.8 & 21.2 & 20.6 & 19.9 \\
\hline Qatar & QAT & 21.1 & 20.9 & 21.0 & 22.0 & 21.1 & 21.8 & 20.7 & 20.9 & 20.3 & 19.0 & 18.6 & 18.8 & 18.4 & 17.8 \\
\hline Romania & ROM & 33.7 & 31.8 & 31.1 & 32.0 & 30.3 & 29.6 & 30.2 & 30.1 & 33.5 & 34.4 & 33.0 & 32.5 & 32.7 & 30.7 \\
\hline Russian Federation & RUS & 43.1 & 35.2 & 43.6 & 44.4 & 44.1 & 44.9 & 46.3 & 45.0 & 40.5 & 41.9 & 41.9 & 42.9 & 42.8 & 40.9 \\
\hline Rwanda & RWA & 37.0 & 37.6 & 37.2 & 35.4 & 36.7 & 37.9 & 35.1 & 36.5 & 39.5 & 40.3 & 39.9 & 40.7 & 40.1 & 39.0 \\
\hline Saudi Arabia & SAU & 19.4 & 18.7 & 18.5 & 18.5 & 18.1 & 17.8 & 18.3 & 19.1 & 18.6 & 18.4 & 18.5 & 18.3 & 17.4 & 16.8 \\
\hline Senegal & SEN & 44.0 & 43.7 & 45.3 & 45.6 & 44.1 & 45.5 & 46.3 & 44.8 & 45.4 & 45.1 & 45.7 & 43.9 & 42.5 & 40.4 \\
\hline Sierra Leone & SLE & 43.3 & 42.7 & 44.1 & 43.6 & 43.0 & 44.9 & 44.3 & 45.0 & 46.7 & 48.6 & 46.0 & 46.6 & 44.1 & 42.9 \\
\hline Singapore & SGP & 13.3 & 13.0 & 12.9 & 12.2 & 11.8 & 12.4 & 12.1 & 13.2 & 12.7 & 13.1 & 13.6 & 13.9 & 13.2 & 12.0 \\
\hline Slovak Republic & SVK & 18.9 & 19.8 & 19.4 & 18.2 & 17.8 & 18.8 & 17.7 & 18.3 & 17.5 & 17.6 & 17.3 & 17.3 & 16.7 & 15.3 \\
\hline Slovenia & SVN & 25.1 & 27.2 & 27.9 & 26.8 & 25.0 & 24.5 & 24.8 & 23.6 & 24.7 & 25.2 & 25.6 & 25.0 & 24.2 & 23.1 \\
\hline Solomon Islands & SLB & 33.0 & 33.4 & 33.1 & 30.1 & 30.8 & 28.9 & 28.7 & 29.6 & 31.2 & 33.4 & 34.6 & 35.8 & 35.6 & 35.7 \\
\hline South Africa & ZAF & 29.5 & 29.6 & 30.4 & 30.3 & 27.8 & 29.6 & 29.1 & 28.6 & 29.1 & 28.4 & 29.1 & 29.4 & 28.5 & 26.7 \\
\hline Spain & ESP & 25.1 & 25.2 & 26.4 & 25.7 & 24.8 & 23.7 & 24.2 & 23.3 & 23.5 & 22.7 & 23.2 & 22.7 & 21.4 & 20.9 \\
\hline Sri Lanka & LKA & 48.0 & 47.3 & 46.5 & 46.4 & 47.1 & 45.9 & 46.1 & 45.5 & 45.3 & 44.6 & 45.9 & 46.4 & 46.1 & 45.9 \\
\hline Suriname & SUR & 45.0 & 44.5 & 43.1 & 41.6 & 42.4 & 42.5 & 42.1 & 42.3 & 40.4 & 39.8 & 40.4 & 39.8 & 39.0 & 38.5 \\
\hline Swaziland & SWZ & 43.8 & 42.4 & 44.4 & 44.0 & 42.1 & 43.0 & 44.9 & 44.7 & 44.8 & 41.4 & 41.6 & 41.3 & 39.6 & 40.5 \\
\hline
\end{tabular}


Appendix A

Table A.1: Size and development of the shadow economy, 1991 to 2017 - Part I (1991-2004) (cont.)

\begin{tabular}{|c|c|c|c|c|c|c|c|c|c|c|c|c|c|c|c|}
\hline Country & ISO & 1991 & 1992 & 1993 & 1994 & 1995 & 1996 & 1997 & 1998 & 1999 & 2000 & 2001 & 2002 & 2003 & 2004 \\
\hline Sweden & SWE & 13.8 & 14.4 & 15.2 & 14.3 & 13.3 & 13.5 & 13.1 & 13.3 & 13.0 & 12.6 & 12.8 & 13.1 & 12.4 & 11.4 \\
\hline Switzerland & CHE & 7.3 & 7.6 & 7.6 & 7.4 & 7.1 & 7.2 & 7.1 & 6.8 & 7.0 & 6.8 & 6.9 & 7.1 & 7.0 & 6.6 \\
\hline Syrian Arab Republic & SYR & 21.7 & 20.9 & 20.3 & 20.4 & 20.8 & 19.3 & 19.3 & 19.3 & 19.3 & 19.3 & 19.3 & 18.7 & 19.6 & 19.1 \\
\hline Taiwan & TWN & 37.8 & 37.2 & 36.5 & 35.9 & 34.9 & 34.8 & 33.6 & 33.6 & 31.7 & 33.6 & 31.8 & 31.0 & 30.3 & 28.7 \\
\hline Tajikistan & TJK & 39.0 & 47.7 & 47.8 & 46.3 & 45.2 & 46.8 & 45.1 & 45.0 & 43.9 & 43.2 & 43.2 & 42.8 & 41.6 & 42.4 \\
\hline Tanzania & TZA & 67.0 & 66.9 & 65.5 & 64.3 & 60.4 & 59.7 & 59.8 & 57.7 & 58.7 & 58.3 & 58.1 & 58.5 & 57.8 & 58.2 \\
\hline Thailand & THA & 54.3 & 54.1 & 54.0 & 53.0 & 51.5 & 50.1 & 53.1 & 54.1 & 55.4 & 52.6 & 54.6 & 52.8 & 52.4 & 51.0 \\
\hline Togo & TGO & 36.5 & 34.8 & 39.3 & 39.1 & 36.9 & 35.4 & 35.5 & 35.0 & 35.7 & 35.1 & 35.8 & 34.0 & 33.3 & 33.6 \\
\hline Trinidad and Tobago & TTO & 39.9 & 40.4 & 40.2 & 38.7 & 39.0 & 37.9 & 38.6 & 36.7 & 37.7 & 34.4 & 36.0 & 35.0 & 33.9 & 33.0 \\
\hline Tunisia & TUN & 40.0 & 38.6 & 39.1 & 38.4 & 37.4 & 37.5 & 37.9 & 38.1 & 37.4 & 38.4 & 37.1 & 37.8 & 36.8 & 34.0 \\
\hline Turkey & TUR & 35.0 & 35.2 & 34.8 & 33.5 & 31.9 & 32.3 & 31.7 & 31.2 & 33.3 & 32.1 & 32.8 & 32.9 & 31.4 & 29.8 \\
\hline Uganda & UGA & 41.0 & 41.8 & 42.8 & 42.4 & 40.0 & 40.4 & 40.8 & 41.4 & 40.9 & 43.1 & 42.8 & 43.7 & 42.8 & 41.3 \\
\hline Ukraine & UKR & 48.7 & 49.2 & 48.5 & 50.6 & 50.9 & 52.2 & 55.7 & 55.7 & 51.1 & 52.2 & 49.6 & 48.5 & 47.7 & 44.5 \\
\hline United Arab Emirates & ARE & 29.9 & 30.1 & 30.4 & 30.2 & 29.4 & 28.1 & 28.5 & 29.6 & 29.3 & 26.4 & 27.5 & 27.0 & 26.3 & 24.9 \\
\hline United Kingdom & GBR & 12.7 & 12.7 & 12.6 & 12.3 & 11.5 & 11.3 & 10.8 & 10.6 & 10.8 & 10.8 & 11.0 & 11.1 & 10.8 & 10.4 \\
\hline United States & USA & 9.5 & 9.3 & 9.1 & 8.8 & 8.5 & 8.5 & 8.1 & 7.9 & 7.8 & 7.6 & 7.8 & 8.1 & 7.9 & 7.8 \\
\hline Uruguay & URY & 48.4 & 47.1 & 47.6 & 46.2 & 45.9 & 47.6 & 43.4 & 43.3 & 45.7 & 46.1 & 46.8 & 47.9 & 46.4 & 44.4 \\
\hline Venezuela, RB & VEN & 36.2 & 36.2 & 36.2 & 36.0 & 35.9 & 33.2 & 37.6 & 37.7 & 38.3 & 36.0 & 38.2 & 37.4 & 37.5 & 35.4 \\
\hline Vietnam & VNM & 21.3 & 20.1 & 20.8 & 21.0 & 20.9 & 20.6 & 20.5 & 20.1 & 19.7 & 19.2 & 19.2 & 19.3 & 19.0 & 18.7 \\
\hline Yemen, Rep. & YEM & 29.7 & 29.8 & 30.5 & 31.1 & 29.1 & 28.4 & 28.7 & 29.4 & 28.4 & 27.4 & 27.4 & 28.0 & 26.7 & 25.7 \\
\hline Zambia & ZMB & 55.7 & 49.5 & 51.0 & 48.6 & 49.0 & 51.9 & 51.0 & 51.6 & 50.1 & 48.9 & 48.9 & 48.5 & 49.4 & 49.2 \\
\hline Zimbabwe & ZWE & 55.7 & 60.1 & 57.2 & 56.8 & 56.4 & 53.2 & 54.0 & 53.8 & 57.8 & 59.4 & 58.2 & 58.9 & 59.5 & 60.1 \\
\hline
\end{tabular}


Appendix A

Table A.1: Size and development of the shadow economy, 1991 to 2017 - Part II (2005-2017)

\begin{tabular}{|c|c|c|c|c|c|c|c|c|c|c|c|c|c|c|}
\hline Country & ISO & 2005 & 2006 & 2007 & 2008 & 2009 & 2010 & 2011 & 2012 & 2013 & 2014 & 2015 & 2016 & 2017 \\
\hline Albania & ALB & 31.6 & 30.5 & 28.7 & 27.3 & 28.0 & 27.9 & 27.0 & 27.7 & 27.5 & 27.0 & 28.2 & 27.8 & 27.0 \\
\hline Algeria & DZA & 28.8 & 27.9 & 27.2 & 25.5 & 29.4 & 28.8 & 28.6 & 28.4 & 28.0 & 28.6 & 32.4 & 32.9 & 32.0 \\
\hline Angola & AGO & 43.8 & 42.0 & 40.5 & 37.7 & 39.9 & 39.2 & 36.9 & 36.1 & 36.3 & 35.2 & 38.8 & 40.6 & 39.1 \\
\hline Argentina & ARG & 26.3 & 25.7 & 24.9 & 23.8 & 25.3 & 23.3 & 21.5 & 22.0 & 22.2 & 23.1 & 22.4 & 22.3 & 20.9 \\
\hline Armenia & ARM & 42.3 & 42.0 & 39.3 & 36.2 & 41.8 & 40.5 & 38.9 & 36.5 & 36.2 & 35.9 & 38.4 & 36.7 & 34.5 \\
\hline Australia & AUS & 12.1 & 11.6 & 11.1 & 10.3 & 10.9 & 11.1 & 10.1 & 9.8 & 9.8 & 9.4 & 10.5 & 11.8 & 11.6 \\
\hline Austria & AUT & 7.6 & 7.3 & 6.4 & 6.4 & 7.8 & 7.6 & 6.9 & 7.0 & 7.0 & 6.6 & 7.3 & 7.4 & 7.1 \\
\hline Azerbaijan & AZE & 52.4 & 50.9 & 49.1 & 45.6 & 49.3 & 47.5 & 44.1 & 43.6 & 42.4 & 42.7 & 48.1 & 49.8 & 48.6 \\
\hline Bahamas, The & BHS & 25.1 & 25.1 & 24.6 & 25.6 & 28.3 & 28.3 & 28.7 & 28.0 & 27.8 & 27.1 & 27.4 & 27.6 & 28.0 \\
\hline Bahrain & BHR & 16.1 & 15.8 & 15.1 & 14.2 & 16.4 & 15.9 & 14.6 & 14.4 & 13.9 & 14.1 & 15.4 & 15.6 & 15.1 \\
\hline Bangladesh & BGD & 35.0 & 34.9 & 33.9 & 32.1 & 31.6 & 31.0 & 29.1 & 29.4 & 28.6 & 27.6 & 26.9 & 26.6 & 25.9 \\
\hline Belarus & BLR & 47.2 & 45.1 & 42.4 & 37.7 & 40.5 & 38.7 & 34.5 & 33.5 & 33.3 & 33.1 & 37.8 & 39.2 & 37.5 \\
\hline Belgium & BEL & 18.1 & 17.7 & 16.1 & 15.5 & 17.4 & 16.9 & 16.0 & 16.7 & 16.6 & 15.9 & 17.2 & 16.9 & 16.5 \\
\hline Belize & BLZ & 44.3 & 41.8 & 42.6 & 41.8 & 46.0 & 45.0 & 42.8 & 41.4 & 41.2 & 41.1 & 41.0 & 43.9 & 43.7 \\
\hline Benin & BEN & 50.2 & 50.4 & 46.6 & 45.7 & 49.0 & 48.9 & 48.3 & 47.3 & 43.9 & 40.0 & 47.6 & 44.9 & 41.5 \\
\hline Bhutan & BTN & 26.5 & 25.8 & 23.6 & 23.6 & 24.9 & 23.1 & 22.2 & 22.3 & 21.6 & 21.0 & 20.6 & 20.6 & 19.0 \\
\hline Bolivia & BOL & 67.5 & 63.3 & 61.6 & 58.0 & 61.7 & 58.1 & 54.5 & 52.0 & 51.1 & 50.7 & 57.1 & 58.2 & 55.8 \\
\hline Bosnia and Herzegovina & BIH & 32.7 & 31.6 & 31.3 & 30.0 & 32.4 & 31.9 & 30.5 & 30.9 & 29.7 & 29.3 & 30.1 & 28.9 & 26.9 \\
\hline Botswana & BWA & 28.4 & 28.1 & 26.9 & 27.3 & 29.0 & 26.1 & 23.3 & 22.6 & 23.1 & 22.8 & 25.3 & 25.6 & 26.0 \\
\hline Brazil & BRA & 38.5 & 37.3 & 35.9 & 33.6 & 35.1 & 30.8 & 28.2 & 29.1 & 29.3 & 29.9 & 33.6 & 34.6 & 33.8 \\
\hline Brunei Darussalam & BRN & 28.1 & 27.2 & 27.7 & 24.0 & 27.1 & 26.3 & 22.1 & 21.5 & 22.7 & 24.9 & 29.8 & 30.3 & 30.2 \\
\hline Bulgaria & BGR & 30.8 & 29.6 & 26.6 & 25.5 & 26.4 & 26.2 & 24.4 & 24.5 & 24.8 & 24.2 & 24.9 & 24.0 & 22.9 \\
\hline Burkina Faso & BFA & 37.0 & 37.2 & 37.2 & 34.0 & 33.7 & 31.9 & 29.6 & 29.3 & 30.5 & 31.4 & 34.0 & 34.0 & 33.1 \\
\hline Burundi & BDI & 36.5 & 35.0 & 36.7 & 35.1 & 35.9 & 35.5 & 34.7 & 34.6 & 34.5 & 34.4 & 34.6 & 36.4 & 32.7 \\
\hline Cabo Verde & CPV & 34.2 & 30.4 & 28.0 & 26.1 & 28.6 & 29.0 & 27.4 & 27.4 & 27.4 & 27.5 & 29.3 & 28.6 & 27.3 \\
\hline Cambodia & KHM & 45.4 & 42.2 & 40.1 & 48.4 & 47.9 & 47.9 & 47.0 & 46.3 & 47.1 & 46.3 & 47.4 & 49.7 & 40.8 \\
\hline
\end{tabular}


Appendix A

Table A.1: Size and development of the shadow economy, 1991 to 2017 - Part II (2005-2017)

\begin{tabular}{|c|c|c|c|c|c|c|c|c|c|c|c|c|c|c|}
\hline Country & ISO & 2005 & 2006 & 2007 & 2008 & 2009 & 2010 & 2011 & 2012 & 2013 & 2014 & 2015 & 2016 & 2017 \\
\hline Cameroon & CMR & 30.3 & 28.9 & 27.6 & 26.6 & 29.0 & 28.6 & 27.8 & 28.3 & 27.7 & 26.4 & 28.9 & 29.3 & 28.0 \\
\hline Canada & CAN & 12.7 & 12.0 & 11.6 & 11.5 & 13.2 & 12.2 & 11.7 & 11.6 & 11.5 & 11.1 & 12.1 & 12.3 & 12.0 \\
\hline Central African Republic & CAF & 39.4 & 38.0 & 36.5 & 35.4 & 35.3 & 34.7 & 32.8 & 32.9 & 38.8 & 36.2 & 35.7 & 35.9 & 34.5 \\
\hline Chad & TCD & 39.3 & 38.4 & 38.0 & 37.0 & 38.5 & 37.1 & 35.8 & 36.1 & 36.2 & 34.4 & 38.0 & 39.9 & 39.3 \\
\hline Chile & CHL & 16.4 & 15.4 & 15.0 & 14.9 & 16.7 & 15.2 & 14.1 & 14.1 & 14.3 & 14.8 & 15.9 & 16.9 & 16.8 \\
\hline China & CHN & 14.0 & 13.9 & 13.2 & 12.6 & 12.8 & 12.1 & 11.8 & 11.9 & 11.6 & 11.0 & 11.5 & 11.3 & 11.1 \\
\hline Colombia & COL & 33.7 & 31.9 & 31.3 & 28.9 & 31.4 & 29.9 & 25.7 & 25.2 & 25.8 & 26.0 & 28.6 & 30.0 & 29.9 \\
\hline Comoros & COM & 33.1 & 32.4 & 32.2 & 29.2 & 29.5 & 28.5 & 26.4 & 26.5 & 25.6 & 25.6 & 29.1 & 30.1 & 27.9 \\
\hline Congo, Dem. Rep. & COD & 51.8 & 50.9 & 48.0 & 46.7 & 49.0 & 46.0 & 45.0 & 45.0 & 43.1 & 41.7 & 43.4 & 44.5 & 43.0 \\
\hline Congo, Rep. & COG & 45.1 & 42.3 & 43.4 & 38.3 & 41.6 & 37.8 & 35.1 & 37.7 & 37.2 & 37.5 & 43.7 & 43.7 & 42.2 \\
\hline Costa Rica & CRI & 23.2 & 22.9 & 22.7 & 22.1 & 23.7 & 23.4 & 23.1 & 22.4 & 22.2 & 22.0 & 21.7 & 21.4 & 21.2 \\
\hline Cote d'Ivoire & CIV & 39.3 & 38.5 & 37.7 & 35.6 & 35.2 & 34.6 & 34.5 & 34.2 & 33.2 & 31.7 & 33.0 & 33.6 & 33.7 \\
\hline Croatia & HRV & 25.8 & 25.1 & 23.6 & 21.6 & 24.4 & 24.6 & 23.7 & 24.6 & 24.0 & 23.8 & 24.7 & 23.6 & 22.7 \\
\hline Cyprus & CYP & 27.5 & 26.7 & 24.7 & 23.1 & 26.0 & 26.0 & 26.2 & 27.1 & 27.0 & 25.6 & 26.6 & 26.7 & 25.2 \\
\hline Czech Republic & CZE & 15.1 & 14.3 & 13.0 & 12.1 & 13.8 & 13.5 & 12.4 & 12.5 & 12.7 & 12.1 & 12.2 & 12.3 & 11.7 \\
\hline Denmark & DNK & 12.6 & 11.8 & 11.2 & 10.9 & 13.3 & 13.0 & 12.0 & 12.4 & 11.9 & 11.1 & 12.0 & 12.1 & 11.7 \\
\hline Dominican Republic & DOM & 31.5 & 31.0 & 30.4 & 30.3 & 31.8 & 30.3 & 29.2 & 29.0 & 28.6 & 28.0 & 28.6 & 27.5 & 27.5 \\
\hline Ecuador & ECU & 33.0 & 32.3 & 31.8 & 30.8 & 33.9 & 31.8 & 30.0 & 29.7 & 29.2 & 29.2 & 31.0 & 31.3 & 30.6 \\
\hline Egypt, Arab Rep. & EGY & 36.3 & 35.4 & 32.8 & 30.1 & 31.0 & 30.5 & 31.3 & 29.9 & 30.3 & 31.0 & 30.3 & 30.0 & 30.7 \\
\hline EI Salvador & SLV & 43.4 & 43.0 & 42.1 & 41.4 & 44.7 & 43.2 & 40.8 & 40.2 & 39.6 & 38.6 & 38.8 & 39.1 & 39.2 \\
\hline Equatorial Guinea & GNQ & 28.7 & 29.0 & 26.7 & 23.9 & 27.6 & 26.4 & 26.0 & 26.0 & 28.1 & 29.1 & 34.0 & 35.6 & 35.1 \\
\hline Estonia & EST & 23.7 & 22.3 & 21.0 & 21.1 & 24.1 & 22.7 & 20.1 & 20.0 & 19.6 & 19.3 & 21.0 & 20.9 & 20.1 \\
\hline Ethiopia & ETH & 37.8 & 36.0 & 34.5 & 33.3 & 32.9 & 33.5 & 31.7 & 29.4 & 29.6 & 28.0 & 27.2 & 27.0 & 26.9 \\
\hline Fiji & FJI & 26.7 & 27.3 & 26.6 & 27.6 & 30.1 & 29.6 & 27.9 & 27.5 & 26.9 & 24.9 & 25.3 & 24.4 & 23.4 \\
\hline Finland & FIN & 11.3 & 10.9 & 10.1 & 9.7 & 11.3 & 11.1 & 10.6 & 11.1 & 11.1 & 10.6 & 11.5 & 11.4 & 10.8 \\
\hline France & FRA & 12.5 & 11.8 & 10.8 & 10.1 & 12.1 & 11.8 & 11.1 & 11.7 & 11.6 & 11.4 & 12.2 & 12.2 & 11.7 \\
\hline
\end{tabular}


Appendix A

Table A.1: Size and development of the shadow economy, 1991 to 2017 - Part II (2005-2017)

\begin{tabular}{|c|c|c|c|c|c|c|c|c|c|c|c|c|c|c|}
\hline Country & ISO & 2005 & 2006 & 2007 & 2008 & 2009 & 2010 & 2011 & 2012 & 2013 & 2014 & 2015 & 2016 & 2017 \\
\hline Gabon & GAB & 49.7 & 50.3 & 48.8 & 44.0 & 51.6 & 46.7 & 42.3 & 44.6 & 45.7 & 48.6 & 52.6 & 53.9 & 52.1 \\
\hline Gambia, The & GMB & 45.8 & 45.9 & 44.4 & 44.4 & 45.5 & 45.6 & 46.4 & 45.5 & 42.5 & 45.3 & 45.8 & 45.3 & 44.0 \\
\hline Georgia & GEO & 65.2 & 62.2 & 62.0 & 60.8 & 62.8 & 59.8 & 54.9 & 52.5 & 51.2 & 50.4 & 53.5 & 53.4 & 51.5 \\
\hline Germany & DEU & 10.9 & 10.0 & 8.9 & 8.7 & 11.0 & 10.6 & 9.5 & 9.9 & 9.9 & 9.2 & 10.2 & 10.7 & 10.4 \\
\hline Ghana & GHA & 46.1 & 39.8 & 38.6 & 38.0 & 37.8 & 35.7 & 38.5 & 36.2 & 31.9 & 34.3 & 33.9 & 33.2 & 31.8 \\
\hline Greece & GRC & 23.5 & 22.5 & 20.9 & 19.7 & 22.8 & 23.1 & 23.0 & 24.3 & 23.7 & 23.6 & 25.3 & 25.4 & 24.8 \\
\hline Guatemala & GTM & 50.4 & 49.5 & 48.8 & 48.2 & 50.2 & 48.2 & 46.6 & 46.8 & 46.7 & 44.8 & 43.4 & 43.4 & 42.0 \\
\hline Guinea & GIN & 39.4 & 36.8 & 32.9 & 32.1 & 33.9 & 34.4 & 34.8 & 33.2 & 33.8 & 33.1 & 33.5 & 31.8 & 30.7 \\
\hline Guinea-Bissau & GNB & 36.9 & 35.7 & 32.7 & 30.3 & 30.8 & 31.5 & 27.6 & 32.0 & 30.4 & 32.0 & 30.1 & 29.1 & 26.9 \\
\hline Guyana & GUY & 34.7 & 30.6 & 29.3 & 29.3 & 29.0 & 27.7 & 26.9 & 25.5 & 26.1 & 26.7 & 26.4 & 24.8 & 24.5 \\
\hline Haiti & HTI & 54.7 & 53.4 & 55.7 & 51.2 & 51.2 & 49.2 & 48.4 & 48.3 & 47.5 & 46.7 & 47.3 & 47.9 & 47.2 \\
\hline Honduras & HND & 47.2 & 47.3 & 46.7 & 46.1 & 49.1 & 46.7 & 43.4 & 44.5 & 45.8 & 42.9 & 41.5 & 42.6 & 41.0 \\
\hline Hong Kong SAR, China & HKG & 15.4 & 14.8 & 14.2 & 14.1 & 14.7 & 13.8 & 13.2 & 13.1 & 12.8 & 12.4 & 12.3 & 12.4 & 11.8 \\
\hline Hungary & HUN & 22.3 & 21.5 & 19.7 & 18.9 & 21.2 & 20.7 & 19.7 & 20.4 & 19.9 & 19.8 & 20.8 & 20.5 & 19.8 \\
\hline Iceland & ISL & 12.1 & 12.0 & 10.9 & 12.0 & 13.9 & 13.5 & 12.9 & 12.9 & 12.7 & 12.1 & 12.2 & 11.6 & 10.8 \\
\hline India & IND & 23.1 & 21.7 & 20.9 & 21.6 & 22.8 & 21.1 & 20.6 & 20.1 & 19.7 & 19.5 & 19.6 & 19.0 & 18.5 \\
\hline Indonesia & IDN & 24.5 & 24.5 & 23.7 & 22.9 & 24.3 & 22.1 & 20.8 & 20.9 & 21.2 & 21.0 & 22.1 & 21.6 & 20.5 \\
\hline Iran, Islamic Rep. & IRN & 17.0 & 17.0 & 15.4 & 15.0 & 15.8 & 15.1 & 13.7 & 13.2 & 14.4 & 15.6 & 17.2 & 16.6 & 15.9 \\
\hline Ireland & IRL & 12.2 & 11.8 & 11.4 & 11.8 & 12.6 & 12.3 & 12.0 & 12.0 & 11.7 & 11.0 & 9.5 & 9.7 & 9.6 \\
\hline Israel & ISR & 21.6 & 21.0 & 20.0 & 19.0 & 20.5 & 19.2 & 17.7 & 18.3 & 17.7 & 17.1 & 17.6 & 17.6 & 17.0 \\
\hline Italy & ITA & 21.2 & 20.5 & 18.4 & 18.1 & 21.2 & 20.8 & 18.9 & 20.0 & 20.0 & 19.7 & 20.9 & 20.6 & 19.8 \\
\hline Jamaica & JAM & 34.3 & 32.5 & 32.2 & 31.0 & 35.4 & 34.5 & 32.5 & 32.6 & 32.6 & 31.9 & 31.5 & 31.7 & 29.9 \\
\hline Japan & JPN & 11.5 & 11.6 & 11.5 & 10.7 & 11.0 & 10.0 & 9.3 & 9.2 & 10.7 & 10.8 & 11.7 & 11.1 & 10.8 \\
\hline Jordan & JOR & 16.7 & 16.6 & 16.0 & 14.3 & 15.9 & 15.5 & 15.1 & 14.6 & 14.4 & 14.1 & 14.4 & 14.9 & 14.9 \\
\hline Kazakhstan & KAZ & 40.0 & 38.3 & 37.4 & 34.7 & 37.9 & 35.5 & 32.9 & 33.2 & 31.1 & 32.3 & 35.6 & 37.7 & 35.8 \\
\hline Kenya & KEN & 34.1 & 31.4 & 30.9 & 30.8 & 31.2 & 29.7 & 28.7 & 27.4 & 27.3 & 25.9 & 26.7 & 26.0 & 24.4 \\
\hline
\end{tabular}


Appendix A

Table A.1: Size and development of the shadow economy, 1991 to 2017 - Part II (2005-2017)

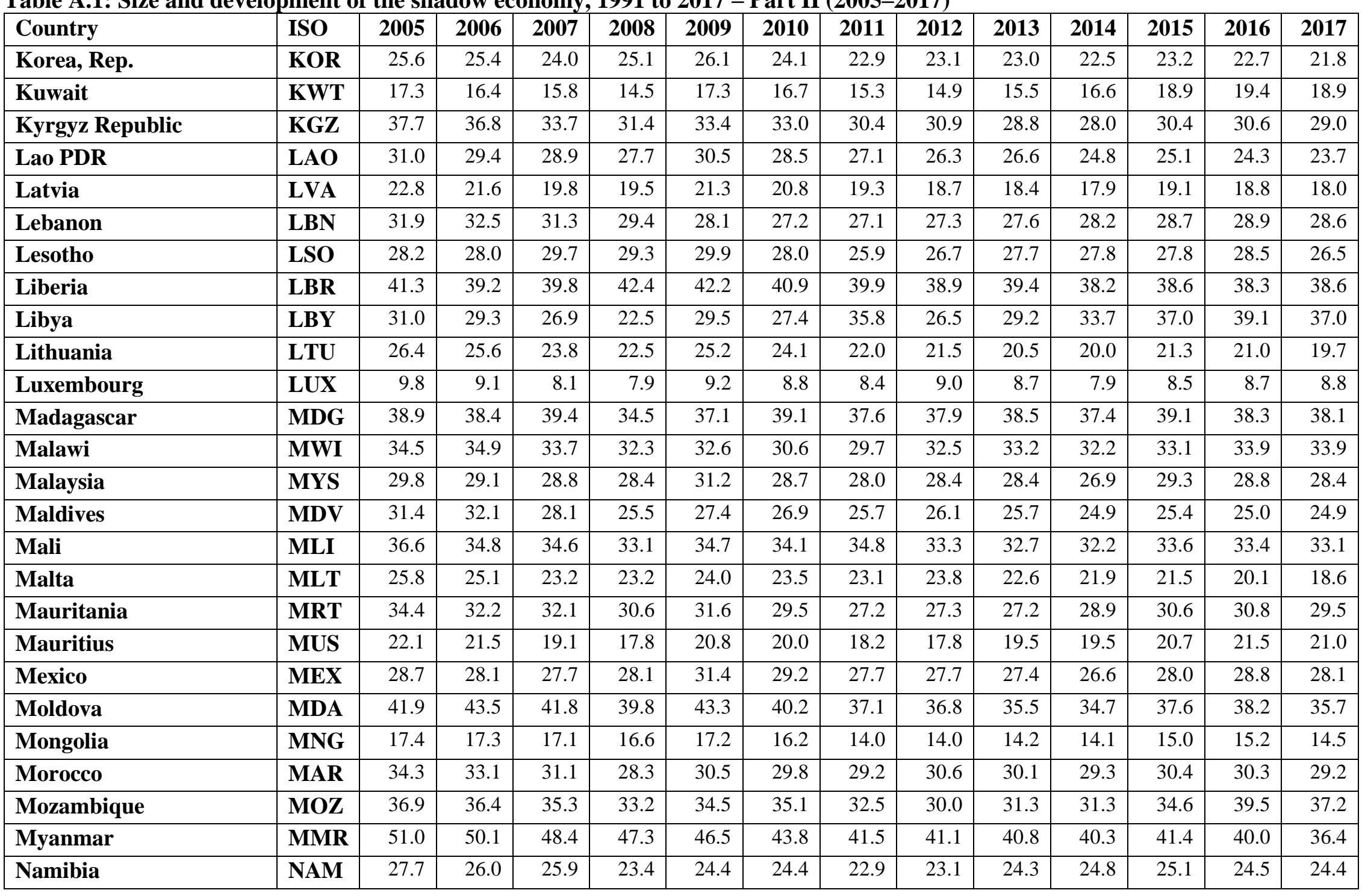


Appendix A

Table A.1: Size and development of the shadow economy, 1991 to 2017 - Part II (2005-2017)

\begin{tabular}{|c|c|c|c|c|c|c|c|c|c|c|c|c|c|c|}
\hline Country & ISO & 2005 & 2006 & 2007 & 2008 & 2009 & 2010 & 2011 & 2012 & 2013 & 2014 & 2015 & 2016 & 2017 \\
\hline Nepal & NPL & 38.1 & 36.7 & 36.8 & 36.5 & 37.9 & 35.5 & 33.7 & 34.7 & 32.7 & 32.0 & 32.0 & 34.0 & 31.1 \\
\hline Netherlands & NLD & 9.6 & 9.4 & 8.8 & 8.4 & 9.4 & 9.4 & 8.9 & 9.1 & 9.0 & 8.6 & 9.0 & 9.1 & 8.8 \\
\hline New Zealand & NZL & 11.0 & 11.3 & 10.7 & 10.9 & 11.7 & 11.0 & 10.3 & 10.4 & 9.9 & 9.5 & 10.0 & 10.1 & 9.7 \\
\hline Nicaragua & NIC & 41.7 & 42.4 & 41.3 & 39.9 & 40.8 & 39.9 & 37.3 & 36.4 & 35.7 & 35.2 & 35.1 & 34.1 & 33.8 \\
\hline Niger & NER & 40.8 & 39.5 & 39.1 & 37.5 & 36.9 & 34.0 & 33.7 & 34.0 & 33.4 & 34.1 & 37.7 & 38.0 & 36.7 \\
\hline Nigeria & NGA & 59.1 & 54.2 & 56.3 & 53.8 & 56.7 & 53.2 & 50.2 & 49.9 & 49.7 & 47.6 & 51.8 & 54.9 & 53.8 \\
\hline Norway & NOR & 11.8 & 10.8 & 10.3 & 9.4 & 12.4 & 11.7 & 10.9 & 10.8 & 10.9 & 11.1 & 12.5 & 13.1 & 12.7 \\
\hline Oman & OMN & 17.8 & 16.9 & 15.9 & 12.6 & 15.7 & 14.1 & 13.5 & 13.3 & 13.7 & 14.8 & 17.3 & 18.4 & 17.4 \\
\hline Pakistan & PAK & 32.8 & 33.0 & 32.9 & 32.1 & 32.9 & 31.8 & 30.9 & 31.2 & 31.2 & 30.6 & 30.6 & 31.7 & 30.1 \\
\hline Papua New Guinea & PNG & 36.6 & 33.9 & 33.3 & 32.9 & 33.1 & 31.8 & 29.8 & 28.4 & 29.1 & 27.8 & 28.9 & 29.1 & 28.7 \\
\hline Paraguay & PRY & 36.8 & 36.1 & 34.5 & 31.8 & 34.6 & 32.2 & 31.0 & 33.0 & 31.1 & 30.7 & 32.6 & 32.3 & 31.0 \\
\hline Peru & PER & 56.6 & 54.1 & 52.1 & 49.8 & 51.7 & 47.2 & 44.4 & 43.6 & 44.0 & 45.6 & 46.9 & 47.3 & 45.9 \\
\hline Philippines & PHL & 39.6 & 39.1 & 38.5 & 37.6 & 40.2 & 38.1 & 37.0 & 37.5 & 36.4 & 35.2 & 35.5 & 35.4 & 34.9 \\
\hline Poland & POL & 24.6 & 24.0 & 22.5 & 20.9 & 22.3 & 21.5 & 20.0 & 20.3 & 19.9 & 19.4 & 20.2 & 20.4 & 19.9 \\
\hline Portugal & PRT & 20.0 & 19.6 & 18.0 & 17.2 & 19.1 & 18.6 & 17.6 & 17.7 & 17.5 & 16.7 & 17.4 & 17.1 & 16.1 \\
\hline Qatar & QAT & 16.6 & 15.8 & 15.5 & 14.6 & 16.9 & 15.8 & 13.8 & 13.1 & 13.5 & 13.9 & 16.3 & 16.8 & 16.6 \\
\hline Romania & ROM & 31.0 & 29.7 & 27.1 & 25.5 & 27.4 & 26.5 & 24.4 & 25.1 & 23.7 & 23.2 & 23.7 & 23.8 & 23.0 \\
\hline Russian Federation & RUS & 40.0 & 39.3 & 37.7 & 35.9 & 40.4 & 36.7 & 32.6 & 32.5 & 32.5 & 33.0 & 37.0 & 38.4 & 36.5 \\
\hline Rwanda & RWA & 38.1 & 37.1 & 34.9 & 32.2 & 31.9 & 31.4 & 29.8 & 29.1 & 28.6 & 28.6 & 28.0 & 28.5 & 27.7 \\
\hline Saudi Arabia & SAU & 15.7 & 15.1 & 14.3 & 12.9 & 15.0 & 13.8 & 12.7 & 12.2 & 12.7 & 13.4 & 15.6 & 14.8 & 15.1 \\
\hline Senegal & SEN & 39.2 & 39.6 & 38.9 & 36.8 & 40.5 & 41.1 & 39.3 & 38.3 & 37.6 & 40.7 & 43.2 & 43.3 & 36.8 \\
\hline Sierra Leone & SLE & 42.0 & 41.4 & 39.6 & 39.2 & 40.0 & 39.2 & 36.1 & 33.0 & 29.1 & 28.4 & 34.1 & 36.6 & 35.4 \\
\hline Singapore & SGP & 11.5 & 11.2 & 10.7 & 10.7 & 11.4 & 10.5 & 9.7 & 9.4 & 9.8 & 9.6 & 10.3 & 10.5 & 10.2 \\
\hline Slovak Republic & SVK & 14.9 & 14.4 & 13.2 & 12.6 & 14.3 & 13.9 & 12.9 & 13.1 & 12.9 & 12.9 & 13.6 & 13.2 & 13.1 \\
\hline Slovenia & SVN & 22.9 & 21.8 & 19.2 & 18.3 & 21.3 & 21.9 & 20.9 & 21.7 & 20.8 & 19.7 & 20.7 & 20.2 & 19.0 \\
\hline Solomon Islands & SLB & 36.1 & 35.8 & 33.3 & 30.8 & 31.9 & 29.6 & 26.5 & 25.4 & 25.1 & 25.2 & 26.1 & 25.4 & 24.5 \\
\hline
\end{tabular}


Appendix A: Table A.1: Size and development of the shadow economy, 1991 to 2017 - Part II (2005-2017)

\begin{tabular}{|c|c|c|c|c|c|c|c|c|c|c|c|c|c|c|}
\hline Country & ISO & 2005 & 2006 & 2007 & 2008 & 2009 & 2010 & 2011 & 2012 & 2013 & 2014 & 2015 & 2016 & 2017 \\
\hline South Africa & ZAF & 26.2 & 22.8 & 22.5 & 23.5 & 25.6 & 23.7 & 21.9 & 23.3 & 24.1 & 24.7 & 26.0 & 27.3 & 26.9 \\
\hline Spain & ESP & 20.6 & 19.9 & 18.7 & 18.6 & 21.3 & 21.3 & 20.6 & 21.3 & 21.1 & 20.9 & 21.9 & 21.3 & 20.3 \\
\hline Sri Lanka & LKA & 46.2 & 47.0 & 46.6 & 46.8 & 48.9 & 41.0 & 38.9 & 38.3 & 38.3 & 37.3 & 36.9 & 36.6 & 35.5 \\
\hline Suriname & SUR & 37.9 & 37.1 & 35.9 & 33.5 & 34.8 & 32.9 & 31.6 & 30.7 & 30.3 & 30.7 & 32.1 & 35.3 & 35.7 \\
\hline Swaziland & SWZ & 39.4 & 38.7 & 38.9 & 40.5 & 40.4 & 37.5 & 35.5 & 35.2 & 36.2 & 36.6 & 39.0 & 41.6 & 39.3 \\
\hline Sweden & SWE & 11.4 & 10.7 & 9.6 & 9.5 & 11.5 & 10.3 & 9.5 & 10.2 & 10.2 & 10.1 & 10.7 & 10.9 & 10.7 \\
\hline Switzerland & CHE & 6.4 & 6.1 & 5.5 & 5.3 & 6.0 & 5.6 & 5.1 & 5.3 & 5.3 & 5.1 & 5.4 & 5.4 & 5.4 \\
\hline Syrian Arab Republic & SYR & 17.6 & 16.5 & 16.1 & 19.4 & 18.3 & 18.5 & 18.7 & 19.1 & 19.6 & 19.3 & 19.4 & 20.0 & 20.0 \\
\hline Taiwan & TWN & 28.2 & 27.7 & 26.8 & 27.1 & 28.5 & 25.7 & 25.3 & 25.2 & 24.7 & 23.3 & 23.3 & 23.2 & 22.8 \\
\hline Tajikistan & TJK & 42.6 & 40.5 & 38.4 & 36.9 & 39.2 & 38.0 & 37.4 & 35.3 & 34.9 & 34.0 & 37.0 & 38.7 & 40.4 \\
\hline Tanzania & TZA & 56.5 & 57.6 & 55.6 & 51.7 & 54.0 & 51.6 & 50.0 & 49.1 & 47.2 & 45.4 & 47.2 & 47.1 & 46.9 \\
\hline Thailand & THA & 50.2 & 49.1 & 48.0 & 46.6 & 49.8 & 46.4 & 44.7 & 43.7 & 43.0 & 44.2 & 45.0 & 44.3 & 41.9 \\
\hline Togo & TGO & 33.9 & 33.6 & 33.8 & 30.5 & 30.7 & 29.8 & 28.7 & 29.9 & 29.2 & 28.7 & 30.4 & 31.6 & 32.1 \\
\hline Trinidad and Tobago & TTO & 32.1 & 32.2 & 31.2 & 28.9 & 32.9 & 31.7 & 30.2 & 30.1 & 29.3 & 28.9 & 29.9 & 31.7 & 31.4 \\
\hline Tunisia & TUN & 33.6 & 32.0 & 29.5 & 26.4 & 29.4 & 28.5 & 30.4 & 30.9 & 31.5 & 31.2 & 34.3 & 35.6 & 35.6 \\
\hline Turkey & TUR & 28.8 & 28.9 & 28.1 & 26.9 & 30.6 & 28.5 & 26.2 & 26.5 & 25.8 & 26.2 & 27.7 & 29.1 & 28.6 \\
\hline Uganda & $\overline{\text { UGA }}$ & 40.3 & 38.4 & 36.3 & 33.5 & 31.6 & 30.9 & 31.9 & 28.4 & 28.1 & 28.0 & 28.8 & 29.4 & 29.8 \\
\hline Ukraine & UKR & 44.2 & 42.9 & 39.0 & 34.9 & 42.9 & 41.0 & 36.7 & 36.3 & 36.3 & 39.6 & 43.6 & 43.0 & 42.3 \\
\hline United Arab Emirates & ARE & 23.5 & 22.5 & 22.2 & 20.7 & 26.1 & 25.9 & 23.1 & 22.0 & 21.5 & 20.8 & 23.1 & 22.7 & 22.1 \\
\hline United Kingdom & GBR & 10.3 & 9.4 & 9.1 & 9.4 & 10.7 & 10.3 & 9.9 & 9.7 & 9.5 & 8.7 & 9.2 & 9.7 & 9.4 \\
\hline United States & USA & 7.4 & 7.1 & 7.0 & 7.0 & 7.8 & 7.4 & 7.0 & 6.7 & 6.6 & 6.1 & 6.1 & 5.9 & 5.7 \\
\hline Uruguay & URY & 43.4 & 42.7 & 41.9 & 40.2 & 41.5 & 38.8 & 36.9 & 37.4 & 36.9 & 36.3 & 37.9 & 40.2 & 39.7 \\
\hline Venezuela, RB & VEN & 33.3 & 32.9 & 32.4 & 30.5 & 33.1 & 29.3 & 31.2 & 29.7 & 29.7 & 28.7 & 33.7 & 34.8 & 35.4 \\
\hline Vietnam & VNM & 17.6 & 17.6 & 17.1 & 16.5 & 16.7 & 16.4 & 15.6 & 15.2 & 14.8 & 14.2 & 14.0 & 13.2 & 12.5 \\
\hline Yemen, Rep. & YEM & 24.8 & 24.5 & 24.0 & 23.4 & 24.4 & 23.1 & 23.3 & 22.9 & 21.8 & 21.5 & 22.1 & 25.4 & 26.6 \\
\hline Zambia & ZMB & 49.9 & 47.6 & 45.6 & 41.9 & 44.6 & 38.1 & 35.6 & 34.7 & 32.5 & 34.7 & 38.3 & 40.4 & 39.3 \\
\hline Zimbabwe & ZWE & 58.1 & 54.4 & 53.7 & 51.9 & 53.5 & 51.0 & 49.5 & 48.0 & 47.0 & 47.4 & 46.5 & 46.5 & 46.0 \\
\hline
\end{tabular}




\section{Appendix B: The problem of "double counting"}

One big problem with macro approaches such as the MIMIC or CDA is that they use causal factors like tax burden, unemployment, self-employment and regulation, which are also responsible for people undertaking do-it-yourself activities or asking friends and neighbors to do things. Hence, do-it-yourself activities, neighbors' or friends help and legally bought material for shadow economy activities are included in these macro approaches. This means that in these macro approaches (including the electricity approach, too) a "total" shadow economy is estimated which includes do-it-yourself activities, neighbors' help, legally bought material and smuggling ${ }^{26}$.

In Table B1 a decomposition of the shadow economy activities for the countries Estonia and Germany is undertaken. Table B1 starts with line (1) of the macro MIMIC estimates of 24.94 percent in Estonia as an average value for 2009 to 2015 and 9.37 percent for Germany for an average over 2009 to 2015. Legally bought material for shadow economy or do-it-yourself activities and friends' help are deducted. Then illegal activities such as smuggling are deducted. Furthermore, do-it-yourself activities and neighbors' help are deducted. Due to these factors from lines (2) to (4) one gets a corrected shadow economy which is roughly two thirds of the macro size of the shadow economy. It is 65 percent for Estonia and 64.2 percent for Germany. In the following, this correction factor is used to calculate an adjusted size of the shadow economy using the MIMIC method. The results for 31 European countries for 2017 are presented in Figure B1. The adjusted shadow economy values appear considerably smaller and this might be a more realistic value of the actual size of the shadow economy using a macro method.

\footnotetext{
${ }^{26}$ A more elaborated and extended discussion is done in Feld and Schneider (2016), and in Medina and Schneider (2018)
} 
Table B1. Decomposition of shadow economy activities in Estonia and Germany

\begin{tabular}{|c|c|c|c|c|c|}
\hline \multirow[b]{2}{*}{ No. } & \multirow{2}{*}{$\begin{array}{l}\text { Kinds of shadow economy activities } \\
\text { (rough estimates!) }\end{array}$} & \multicolumn{2}{|l|}{ Estonia } & \multicolumn{2}{|c|}{ Germany } \\
\hline & & $\begin{array}{l}\text { Size in } \\
\text { percent } \\
\text { of } \\
\text { official } \\
\text { GDP } \\
\text { average } \\
2009- \\
2015\end{array}$ & $\begin{array}{l}\text { Proportion } \\
\text { of total } \\
\text { shadow } \\
\text { economy } \\
\text { (percent) }\end{array}$ & $\begin{array}{l}\text { Size in } \\
\text { percent } \\
\text { of } \\
\text { official } \\
\text { GDP } \\
\text { average } \\
2009- \\
2015\end{array}$ & $\begin{array}{l}\text { Proportion } \\
\text { of total } \\
\text { shadow } \\
\text { economy } \\
\text { (percent) }\end{array}$ \\
\hline 1 & $\begin{array}{l}\text { Total shadow economy (estimated by } \\
\text { the MIMIC and calibrated by the } \\
\text { currency demand procedures) }\end{array}$ & 24.94 & 100 & 9.37 & 100 \\
\hline 2 & $\begin{array}{l}\text { Legally bought material for shadow } \\
\text { economy and DIY activities }\end{array}$ & 5.24 & 21 & 1.79 & 19.1 \\
\hline 3 & Illegal activities (smuggling etc.) & 1.75 & 7 & 0.69 & 7.4 \\
\hline 4 & $\begin{array}{l}\text { Do-it-yourself activities and } \\
\text { neighbors' help }{ }^{1)}\end{array}$ & 1.75 & 7 & 0.86 & 9.2 \\
\hline 5 & Sum (2), (3) and (4) & 8.73 & 35 & 3.35 & 35.7 \\
\hline 6 & $\begin{array}{l}\text { "Corrected" shadow economy, but } \\
\text { legal activities (position (1) minus } \\
\text { position (5)) }\end{array}$ & 16.21 & 65 & 6.02 & 64.2 \\
\hline & \multicolumn{5}{|c|}{${ }^{1)}$ Without legally bought material which is included in (2) } \\
\hline
\end{tabular}

Source: Own calculations based on the work of Enste and Schneider (2006) and Buehn and Schneider (2012), p.12., and Feld and Schneider (2016) 


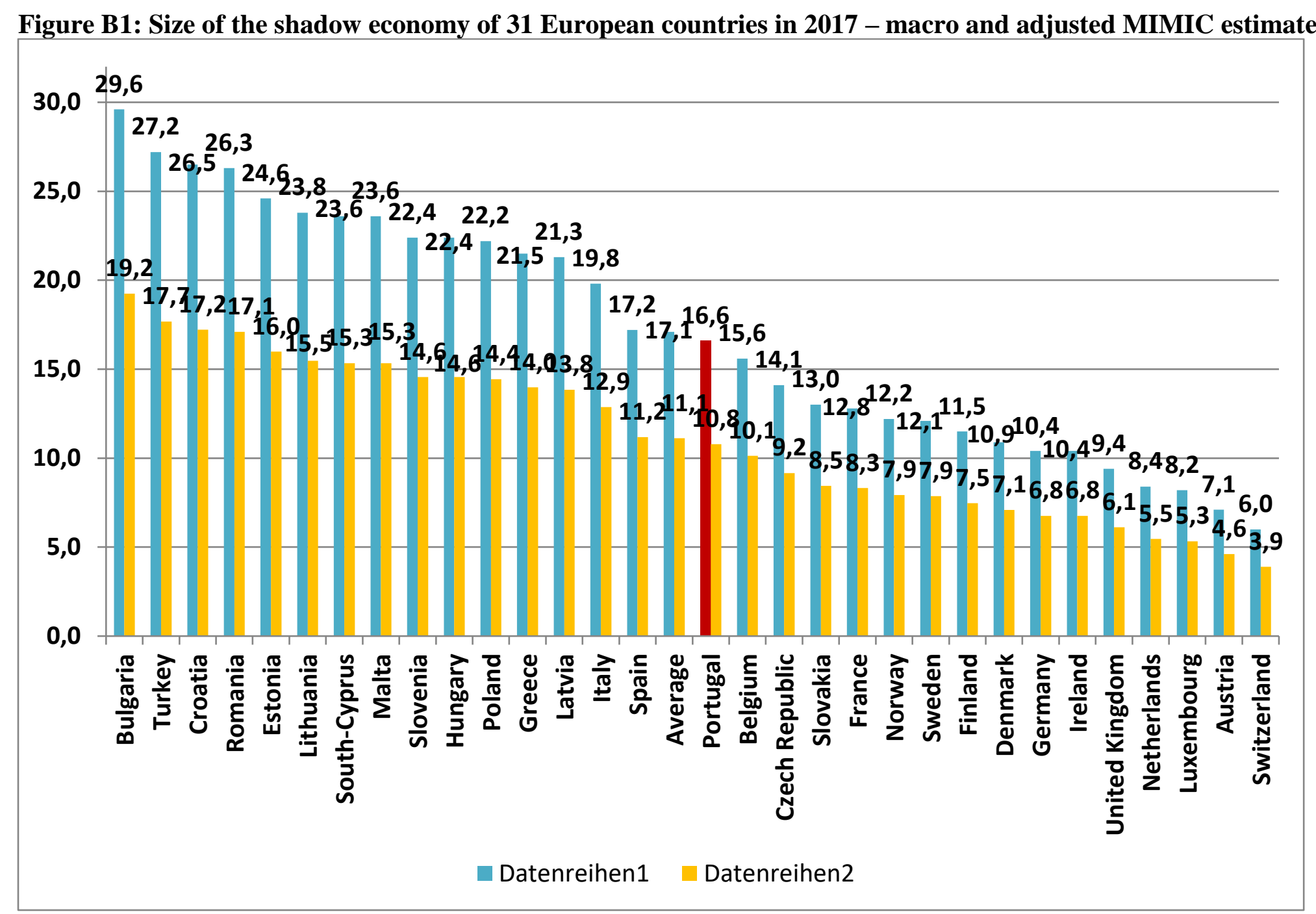

Source: Own calculations. 